CUPAUAM 21, 1994, pp. 183-234

\title{
PRODUCCIONES ATLÁNTICAS DE TERRA SIGILLATA GÁLICA TARDÍA EN LA COSTA CANTÁBRICA DE HISPANIA"
}

\author{
ALEXANDRA USCATESCU \\ CARMEN FERNÁNDEZ OCHOA \\ PALOMA GaRcía DÍAZ ${ }^{1}$
}

\section{Resumen}

Este artículo, y con motivo del hallazgo de un importante lote de terra sigillata gálica tardía procedente de las Termas romanas de Gijón (Asturias), presenta una revisión de algunas piezas gálicas halladas en distintos yacimientos cantábricos o en áreas próximas directamente comunicadas con Aquitania. En el caso gijonés, este descubrimiento adquiere una mayor relevancia al localizarse dentro de un depósito tardío (segunda mitad del siglo $\mathrm{v}$ al primer cuarto del siglo vi d.C.) y de ser uno de los pocos lotes hispánicos originarios del taller atlántico francés, con un posible centro en Burdeos.

Además, junto a las auténticas t.s.g.t. se ha determinado la existencia de un pequeño grupo de imitaciones hispánicas de t.s.g.t. reflejo, sin duda, de la gran influencia que ejercieron los modelos gálicos importados en algunas producciones locales o regionales peninsulares.

\section{Summary}

This paper is mainly concerned with a revision of a late Roman fine ware, known as Gaulish t.s. grise found in several Cantabrian sites and near areas, well connected with Aquitaine. The rencent find from the Roman Thermae of Gijón (Asturias) provides one of the few well-dated evidences. It was recovered from a late deposit dated to the second half of the 5 th century till the first quarter of the 6th century $\mathrm{AD}$ and is also one of the few Spanish pottery finds from the western French workshops, probably belonging to the Bordeaux production centre.

In Gijón, along with the Atlantic Gaulish t.s. grise finds, a small group of Spanish imitations has been discerned within the Thermae excavations. This group may reflect the influence of some imported Gaulish prototypes attested in various local or regional fine wares.

\footnotetext{
${ }^{1}$ Departamento de Prehistoria y Arqueología de la Universidad Autónoma de Madrid.
} 


\section{LA NOMENCLATURA DE LAS PRODUCCIONES GÁLICAS TARDÍAS}

La nomenclatura de estas producciones gálicas ha sido conflictiva pues desde su primera identificación, y hasta las últimas publicaciones, han recibido numerosas denominaciones ${ }^{2}$. A principios de este siglo fueron divulgadas con el adjetivo de visigodas por J. Déchelette (1904), término desechado radicalmente por J. Rigoir (1968:177) ya que estas manufacturas, cronológicamente, se situaban más de cuarto de siglo antes de la llegada de los visigodos al solar galo. En el caso peninsular, las primeras noticias sobre este tipo cerámico igualmente se remontan a inicios de siglo con la publicación de $\mathrm{M}$. Cazurro (1909-10) autor que, influenciado por J. Déchelette, optó por la misma denominación francesa. No obstante, esta denominación no ha sido radicalmente eliminada puesto que para J. Hayes (1972:404) podría ser admitida en el caso de la producción atlántica de t.s.g.t. ${ }^{3}$.

Un término más general, pero no menos ambiguo, fue el empleado años más tarde por H. Zeiss (1933) que las denominó cerámica de la Antigüedad Tardía (spätantike keramik). Un nombre tan amplio dio cabida no sólo a los productos gálicos sino a todos sus contemporáneos manufacturados en los distintos centros alfareros mediterráneos.

A partir de la segunda década de los años cuarenta se impuso, de forma generalizada, el nombre de cerámica estampada. Esta denominación supuso aún mayores problemas ya que abarcaba a todas las producciones tardías con este tipo de decoración, es decir, a casi toda la sigillata tardía conocida. Dentro de esta corriente cabe destacar el trabajo de P. de Palol (1948) sobre cerámicas estampadas romano cristianas halladas en la Península Ibérica. Esta investigación pionera presenta un problema: bajo la misma denominación (cerámica estampada) se engloban diferentes tipos de importaciones, como t.s.a. ${ }^{4}$ o t.s.g.t. No obstante, P. de Palol diferenció netamente el origen norteafricano de alguno de los punzones decorativos. Una denominación similar (céramique estampée tardive) fue propuesta por M. Gauthier (1975:24) a mediados de los años setenta. Sin embargo, creemos que el adjetivo de estampada no es aceptable porque, además de reunir distintas producciones contemporáneas decoradas con la misma técnica, no todas las producciones gálicas están decoradas con estampación sino que hay versiones lisas, otras decoradas con ruedecilla impresa, etc. Por otro lado, dicha denominación es, etimológicamente, equivalente al término de sigillata, tal y como señaló en su día J. Rigoir (1968:179).

\footnotetext{
${ }^{2}$ Para una breve sintesis historiográfica sobre el desarrollo de la investigación y nomenclatura de estas cerámicas en Francia, desde finales del siglo xIX, vid.: Rigoir 1960:1-2 y Gauthier 1975:17-24.

${ }^{3}$ La aplicación del adjetivo visigodas para las producciones atlánticas, por parte de J. Hayes, se basa en razones de tipo cronológico ya que las cerámicas del taller aquitano se fechaban, fundamentalmente, en el siglo vi d.C. (Hayes 1972:404). Por su parte J. Rigoir (1968:177, nota 2) había señalado la oficialidad de la presencia visigoda en Aquitania desde inicios del siglo $\mathrm{V}$ d.C.

- A lo largo del texto se nombran los distintos tipos de sigillata según las siguientes abreviaturas: $t . s . a$. (terra sigillata africana), t.s.f.t. (terra sigillata focense tardia), t.s.g.t. (terra sigillata gálica tardía) y t.s.h.t. (terra sigillata bispanica tardia).
} 
Con la publicación de J. Rigoir (1960 y 1968) sobre sigillées paléochrétiennes grises et orangées, ampliamente divulgada en España durante la década de los años setenta, los estudios peninsulares sobre t.s.g.t. conocen un nuevo avance.

En España, la investigación estuvo encabezada por L. Caballero (1972), autor de las primeras obras sobre esta producción y el que ha mantenido la denominación de terra sigillata paleocristiana gris y anaranjada hasta la fecha (Caballero 1985:117) por considerala más aceptable que la de visigodas (Caballero 1972:205). A. Bourgeois sostiene la misma postura (Bourgeois y Mayet 1991:367). A partir de los años setenta se afianza esta denominación, aunque otros investigadores continuaron utilizando la nomenclatura de P. de Palol: cerámicas tardorromanas y visigodas anaranjadas y grises con decoración estampada (Mañanes 1980) o cerámicas romano-visigodas con decoración estampada (Romero Carnicero 1974). No obstante, hay que subrayar que la denominación de paleocristianas propuesta y defendida por J. e Y. Rigoir (1987:329) es algo restrictiva ya que resulta demasiado específica, tal y como señalaron M. Gauthier (1975:23-24) o F. Mayet (1984:268), puesto que hace referencia a la decoración. Se trata, en efecto, de un tipo de decoración muy concreta que implica una posición ideológica cristiana, pero el repertorio gálico no sólo se reduce a este modelo de estampillas.

Cuando J. e Y. Rigoir (1971) cambiaron el nombre de estas cerámicas, llamándolas dérivées des sigillées paléochrétiennes se añadió un problema. El término de derivadas ${ }^{5}$, en el caso peninsular, resultó confuso ya que indujo a error y se confundió con el de imitaciones hispánicas de paleocristianas de L. Caballero (1985:117-118), es decir, producciones que imitan a la t.s.g.t. Incluso se llegó a pensar que J. e Y. Rigoir, con el término de derivadas, hacian referencia a ciertas producciones hispánicas que imitaban a las gálicas, sorprendiéndose de que estos autores galos, a pesar del título de su artículo: "Dérivées des sigillées paléochrétiennes en Espagné, no mencionaran ninguna producción hispánica de imitación (Caballero y Argente 1975:141, nota 56). También se han identificado a las aderivadas de sigillata paleocristiana" con imitaciones hispánicas de paleocristianas de una segunda generación (Cerillo 1984-85:362), produciéndose errores de identificación.

Otros investigadores prefirieron obviar los términos propuestos por J. Rigoir de "derivadas" y de paleocristianas" y denominar a estas producciones con términos basados en sus características físicas, llamándolas "t.s. grises y anaranjadas estampadas" (Martínez y Unzueta 1988:20; VV.AA. 1989:156) o simplemente "cerámica gris estampada" (Mezquiriz 1978:45).

Por último, cabe destacar la postura de los estudiosos que defienden la adjudicación de "gentilicios" a las producciones cerámicas. Dentro de esta línea se sitúan todos aquéllos que defienden la indicación del lugar de producción de la sigillata, en lugar de

${ }^{5}$ El término de derivadas, según J. e Y. Rigoir (1987:329), hace refencia a unas cerámicas finas ( $t . s$.a., t.s.f.t. o t.s.g.t., por citar algún ejemplo) que guardan ciertas técnicas y formas de la sigillata pero cuyo tipo de decoración resulta algo nuevo. En realidad, el término de DPS de Rigoir hace referencia a las producciones que, estos mismos autores, denominaban sigillées paléochrétiennes grises et orangées. 
las carácterísticas físicas o simples clasificaciones aleatorias ${ }^{6}$ como, por ejemplo, A. Carandini (VV.AA. 1981:5); este autor incluye la terra sigillata arancione-grigia dentro de las cerámicas narbonenses. Pero el empleo del adjetivo de narbonense tampoco es muy aconsejable, sobre todo, si se tiene en cuenta que, además de Narbona, existen otros centros productores de t.s.g.t. ${ }^{7}$. Un término geográfico más amplio fue el de Gaulish t.s. grise, es decir, terra sigillata gris gálica, empleado por J. Hayes (1972:402) en sus primeras publicaciones, aunque años más tarde volvió a la antigua denominación de Rigoir: t.s. gris paleocristiana (Hayes 1980:533). F. Mayet (1984:268) propuso el empleo de la denominación de sigillata tardia de la Gallia, que es básicamente la que hemos adoptado en nuestro trabajo, si bien el término de sigillata se utiliza de forma convencional, igual que en el caso de otras producciones tardías norteafricanas, microasiáticas o hispánicas. Sin embargo, otros investigadores aun aceptando el nombre de t.s. gálica continuan manteniendo el adjetivo de paleocristiana (Daura y Pardo 1990:149).

En resumen, parece más correcto hablar de terra sigillata gálica tardía incluyendo los adjetivos de gris o anaranjada según el tipo de cocción, oxidante o reductora, para las cerámicas producidas en Gallia, ya sean del grupo atlántico, del provenzal o del narbonense. Los productos hispánicos derivados de aquéllas deben llamarse, simplemente, imitaciones hispánicas (locales o regionales) de t.s.g.t.

\section{LAS PRODUCCIONES DE T.S. GÁLICA TARDÍA DEL GRUPO ATLÁNTICO}

J. Rigoir (1968:181-183) estableció tres centros principales de producción ${ }^{8}$ En primer lugar, el grupo narbonense o del Languedoc, que enlaza directamente con la t.s. narbonense o t.s. clara B de Lamboglia. En segundo lugar, el grupo provenzal con centro en Marsella. Y por último, el grupo atlántico o aquitano con centro en Burdeos ${ }^{9}$. Sin embargo, J. Hayes (1972:403) no estuvo de acuerdo con esta clasificación por talleres de la t.s.g.t.; para este investigador los distintos grupos serían simplemente fases en la evolución de la t.s.g.t. y sólo el grupo atlántico sería producto de una evolución local de la t.s.g.t.

${ }^{6}$ Sirva para ilustrar esta idea el caso de la actualmente denominada terra sigillata focense tardía. En los primeros momentos fue clasificada por F.O. Waagé como el tipo Late Roman C del ágora de Atenas. J. Hayes (1972:323) mantuvo esta denominación hasta que se descubrió el lugar de origen de dicha producción en Focea y entonces pasó a llamarla Pbocaean Red Slip Ware (Hayes 1980:525) o lo que es lo mismo terra sigillata focense.

7 Si se engloban todas las producciones gálicas tardias bajo el nombre de narbonense se llegan a dar contradicciones en las nomenclaturas. Hemos podido observar que algunos autores como L. Caballero (1989:87), adscribiéndose, en parte, a la línea iniciada por A. Carandini, han denominado a algunas cerámicas narbonenses del grupo atlántico, empleando dos téminos incompatibles, pues, o bien es narbonense, o bien es atlántica.

8 Las piezas cantábricas pertenecen, en su gran mayoría, al taller atlántico o aquitano. Las producidas en los talleres de la Narbonense y la Provenza son minoritarias por ello nos remitimos directamente a los trabajos de J. e Y. Rigoir (1968, 1981, 1985 y 1987) a la hora de su definición y caracterización.

9) Aunque, últimamente, se han descubierto nuevos talleres en Carcasona (Courtieu et al. 1980:68). 


\section{Características de la producción}

Las características definidas por J. Rigoir para el grupo atlántico se cumplen perfectamente en la mayoría de las piezas cantábricas ${ }^{10}$. Es la producción más homogénea de todas las gálicas. Fabricada íntegramente a torno, se caracteriza por unas arcillas finas, con desgrasantes también finos, apenas visibles a simple vista, con inclusiones de pirita, calcita o cuarzo (Rigoir y Meffre 1973:207). El engobe, de tonalidad algo más oscura que la de la pasta, es brillante, su tacto jabonoso se obtiene por pulido (Rigoir 1968:185) y, generalmente, está bien adherido a la pasta ${ }^{11}$ En cuanto a las cocciones, hay un predominio casi absoluto de las reductoras, casi no hay producciones anaranjadas (Rigoir 1968:182, mapa 4).

Las formas aquitanas presentan unos perfiles gruesos. En cuanto al repertorio morfológico de esta producción, con respecto a la provenzal o a la narbonense, es menos variado y amplio. Las formas Rigoir 2 y 8 no existen: las formas 3,13,14, 15, 18 y 22 son escasas (Rigoir y Meffre 1973:222), mientras que predominan las formas 1, 4, 6 y 16 de Rigoir.

Por lo que respecta a las decoraciones atlánticas, éstas son también peculiares. Hay un predominio de las decoraciones impresas a ruedecilla. Las estampillas adquieren un marcado carácter cristiano (Rigoir 1968:185) y se caracterizan, además, por su trazo curvilíneo y su aplicación poco profunda. Un rasgo típico del grupo atlántico son las estampillas centrales rodeadas por un círculo impreso a ruedecilla (Courtieu et al. 1980:42). Al contrario de los otros grupos gálicos, no parecen tener contactos con las t.s.a. (Hayes 1972:404). No obstante, esta afirmación de J. Hayes no puede mantenerse ya que existen algunas estampillas aquitanas que muestran una clara influencia norteafricana e incluso oriental y, algunas, se pueden identificar con el repertorio decorativo de J. Hayes. Por ejemplo, una estampilla de círculos concéntricos con guirnalda punteada de Burdeos

${ }^{10}$ En nuestro estudio hemos incluido la $t$.s.g.t. localizada en las excavaciones de las Termas de Gijón y las que se exhiben en el Museo Arqueológico de Oviedo procedentes de Murias de Paraxuga. Otras piezas englobadas o mencionadas en este artículo (cabo de Higuer, Iruaxpe III, Peña Forua, oppidum de Iruna, cueva de Abauntz, Pompaelo, Covairada o Clunia) sólo las conocemos por referencias bibliográficas y no han sido estudiadas directamente. Muchas de estas piezas gálicas, excepto las de Pompaelo y algunas piezas de Peǹa Forua, pudieran pertenecer al grupo atlántico. Resulta bastante difícil la adjudicación de esta $t$.s.g.t. a cualquiera de los tres talleres gálicos contando sólo con datos bibliográficos y dibujos. Como señalaron J. e Y. Rigoir (1971:36), en muchas ocasiones, el método más seguro y fiable en la determinación de la pertenencia de una pieza a cualquiera de los grupos galos sólo se puede basar en las decoraciones y, más concretamente, en el estilo decorativo, criterio no muy objetivo, por otro lado. Por esta razón las conclusiones que se extraen a lo largo del texto referidas, exclusivamente, a las piezas nord-peninsulares halladas fuera de Asturias, no son del todo definitivas en cuanto a su adscripción al taller aquitano.

${ }^{11}$ En el caso de la t.s.g.t. hallada en Asturias no se puede confirmar la buena adherencia del engobe a la pasta. Durante las excavaciones de las Termas de Gijón se ha observado la pérdida del engobe en numerosas producciones cerámicas. Probablemente, por la acidez del mismo suelo las cerámicas finas, bien t.s. hispánica o importada pierden el engobe y las pastas presentan una textura muy blanda e incluso adquieren propiedades típicas de la tiza. 
(Gauthier 1975: fig.5) es muy similar al motivo norteafricano 31m del estilo A (ii) de Hayes, que se fecha en la t.s.a. desde finales del siglo IV d.C. a inicios del V d.C. (Hayes 1972:236, fig.40,31m).

\section{Cronología y dispersión de la t.s.g.t. del grupo atlántico}

La cronología general de la t.s.g.t. es algo imprecisa aunque los talleres atlánticos parecen ser algo más tardíos que el resto (Rigoir 1981:170), fechándose hacia el siglo vi d.C. (Hayes 1972:404: Mayet 1984:268). La fecha más antigua de toda la producción se sitúa en la primera mitad del siglo IV d.C. en el Languedoc (Caballero 1972:206; Palol 1948:459; Rigoir 1968:187). Sin embargo, esta fecha generalizada se estableció en el siglo IV d,C. porque muchas de estas cerámicas aparecían asociadas a monedas de ese siglo ( $A E 3$ y $A E 4$ ). Sin embargo, es bien conocido que estos pequeños bronces continuan circulando mucho tiempo después de su emisión y se encuentran, sin mayores problemas, en contextos de los siglos v y vi d.C., tal y como ocurre en Conímbriga (Mayet 1984:268), Cartago (Hayes 1977,280) o, más concretamente, en la región de Aquitania (Gauthier 1975:334).

Las piezas más modernas aparecen asociadas a enterramientos merovingios del siglo VII d.C. En España parece que ciertas piezas del taller languedociano y del provenzal se documentan en el valle del Ebro a mediados del siglo IV d.C. (Paz 1991:209).

\section{CATALOGO DE HALLAZGOS CANTÁBRICOS}

En los últimos veinte años los hallazgos de t.s.g.t. en la costa cantábrica peninsular y en zonas cercanas a la misma han ido incrementándose (fig. 3$)^{12}$. Conocemos la existencia de este tipo de producciones en Gijón y en Murias de Paraxuga (Asturias), en Abauntz y Pompaelo (Navarra), en el Oppidum de Iruña y en la cueva de Covairada (Alava), en Iruaxpe III y en el fondeadero de cabo Higuer (Guipúzcoa), en Peña Forua (Vizcaya) y en Clunia (Peñalba de Castro, Burgos).

\section{Asturias}

Gijón

Las únicas piezas asturianas que cuentan con un contexto arqueológico datable son las procedentes de las recientes excavaciones de las termas romanas ${ }^{13}$, que habían

\footnotetext{
${ }^{12}$ Los yacimientos franceses que aparecen en el mapa de la figura 3 son, exclusivamente, los mencionados en el texto y corresponden a los paralelos de piezas atlánticas halladas en la Península Ibérica.

13 Estas excavaciones están dirigidas por C. Fernández Ochoa y P. García Díaz del departamento de Prehistoria y Arqueología de la Universidad Autónoma de Madrid.
} 
sido parcialmente excavadas por un erudito local, D. Calixto Alvargonzález en 1903 (Alvargonzález 1965). Otras piezas hispánicas de imitación localizadas en Beloño, Paraxuga y Coaña carecen de cualquier contexto fechable.

En las termas se localizó un importante depósito, de unos $1.20 \mathrm{~m}$ de potencia, de época tardía, situado en las áreas denominadas Z-4, Z-5, Z-6, Z-7 y Z-8 (fig.1). Este depósito aparecía sellado en su parte superior por un nivel de época altomedieval y en su parte inferior por el suelo de las termas de época altoimperial. Esta acumulación se formó con posterioridad a la ruina y desuso del edificio termal y, de forma general, se fecha desde la segunda mitad del siglo $\mathrm{v}$ al primer cuarto del siglo vi d.C.

En el depósito tardío de las termas, junto a la t.s.g.t. se identificaron otras importaciones ${ }^{14}$, como t.s.a. D, - formas Hayes 91C y 99, junto con estampillas del estilo A (ii/iii) también de Hayes-, t.s. focense, - formas 3C, 3E y otra variante de la forma 3 de Hayes-, y varios fragmentos de ánforas del Mediterráneo Oriental - L.R.A. 1-. Dichas importaciones se fechan, principalmente, desde la segunda mitad del siglo $\mathrm{v}$ a mediados del siglo vi d.C.

Los productos gálicos tardíos constituyen uno de los grupos mejor representados en el conjunto de las termas de Gijón (fig.2). Las formas identificadas hasta ahora son: $1,4,16,18$ y 30 de Rigoir.

\section{Murias de Paraxuga (Oviedo)}

Los dos platos de $t . s . g . t$. de la forma Rigoir 1 y 4 (fig. 5,3 y fig. 7,13 ) que incluimos en este estudio fueron hallados durante unas excavaciones de urgencia realizadas por Jordá, allá por la década de los años cincuenta. Durante estos trabajos se descubrió parte de lo que, más tarde, se identificó con una villa tardía (Fernández Ochoa 1982:258-291). Desgraciadamente, no se conoce el contexto arqueológico donde fueron hallados ambos platos que, por otro lado, han sido publicados en numerosas ocasiones (Carrocera y Requejo 1989:29: Encinas y García 1992:132; Requejo 1992:140) pero erróneamente identificados con imitaciones hispánicas de t.s.g.t.

\section{País Vasco}

Oppidum de Iruña (Trespuentes, Alava)

Las noticias sobre la existencia de un vaso gálico se deben, en primer lugar, a su excavador (Nieto Gallo 1958:91; VV.AA. 1989:10) y a una referencia publicada por L. Caballero (1966:138). Actualmente, tanto el yacimiento como los materiales allí exhumados están siendo objeto de revisión (Gil, Filloy e Iriarte 1991:282).

${ }^{14}$ Para una mayor información sobre las cerámicas importadas de este depósito vid: Fdez Ochoa, García y Uscatescu 1992. 


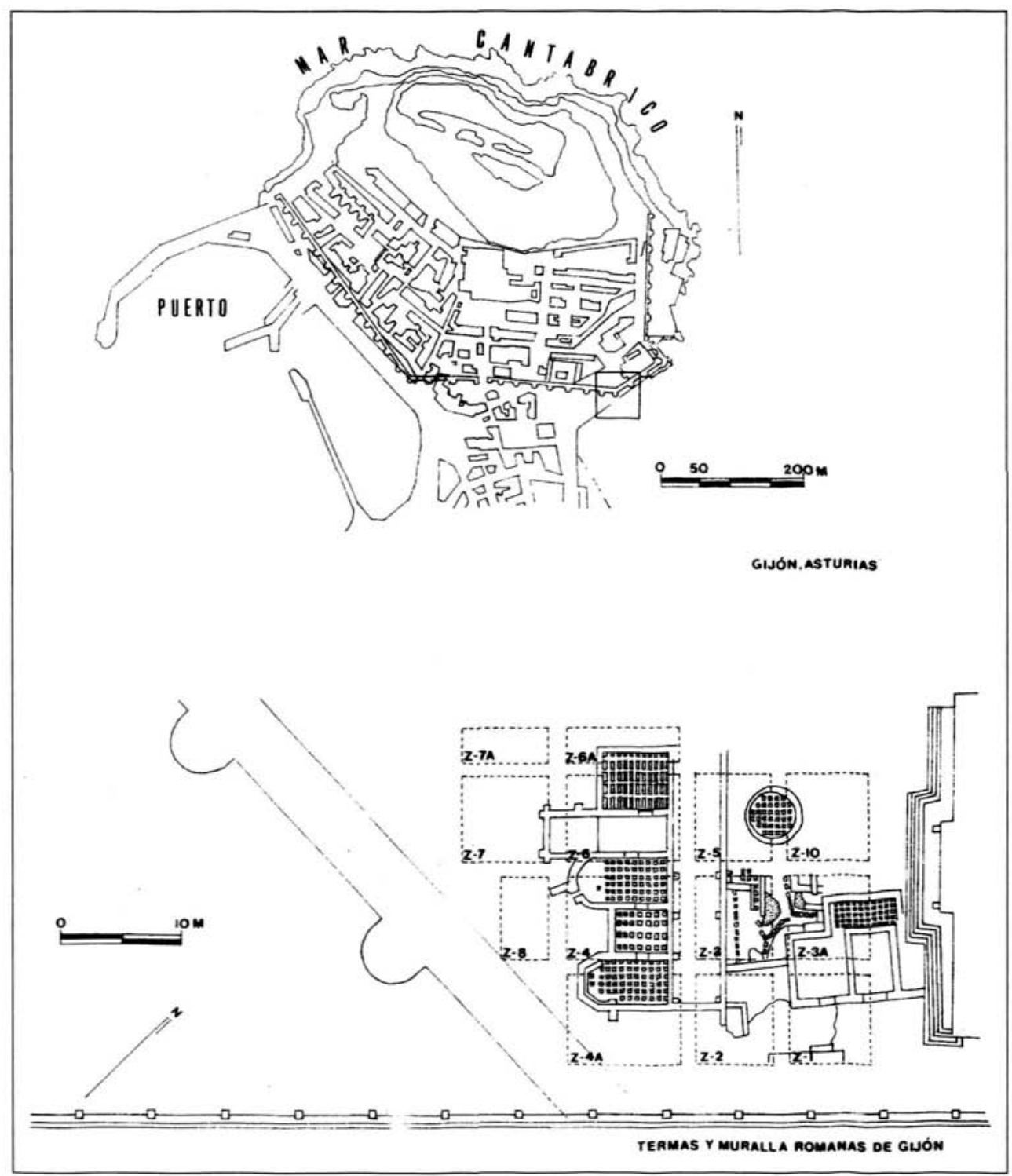

Figura 1. Croquis del casco antiguo de Gijón y de las excavaciones de las Termas romanas

El vaso se halló en el sector $\mathrm{K}$ del yacimiento dentro de un silo, excavado por $\mathrm{G}$. Nieto, junto con dos monedas de Constancio I (Gil, Filloy e Iriarte 1991:285). L. Caballero (Caballero y Argente 1975:143; fig.6) identificó este cuenco con la forma 18 de Rigoir. Sin embargo, el perfil de la pieza de Iruña no corresponde con la típica forma globular de los recipientes gálicos. Su silueta troncocónica resulta una variante de esa forma, pero 
al no haber estudiado la pieza directamente no podemos afirmar taxativamente la adscripción de la misma a una variante de la forma Rigoir 18 o identificarla con una imitación hispánica de t.s.g.t. No obstante, decorativamente, es similar a las piezas languedocianas (fig.12,37).

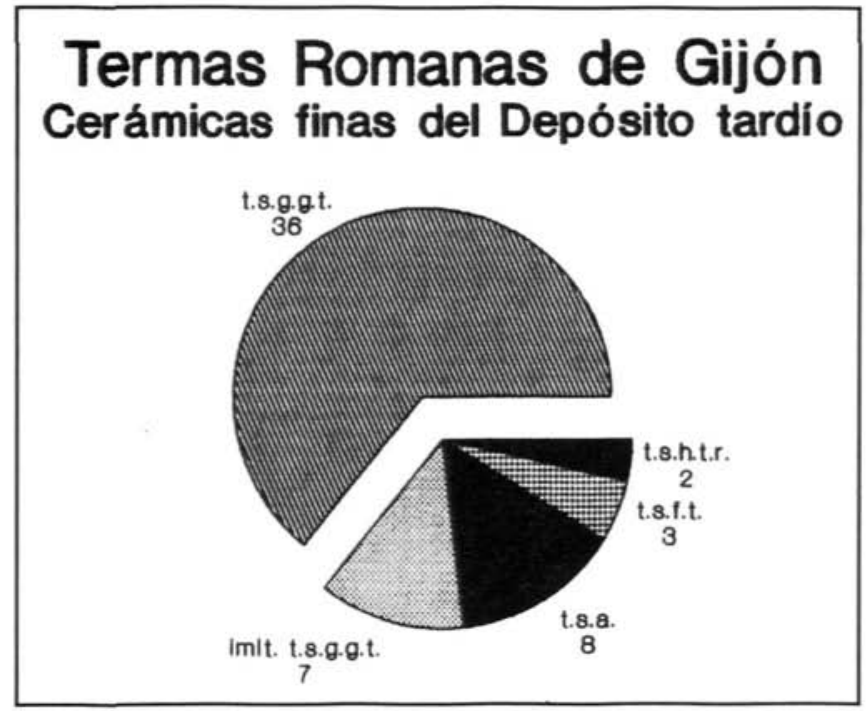

Figura 2. Cerámicas importadas de Gijón (Asturias)

\section{Cueva de Covairada (Álava)}

La existencia de t.s.g.t. la conocemos por distintas citas bibliográficas que mencionan, muy sucintamente, la presencia de sigillata de este tipo en Covairada y ninguna menciona la fuente donde se extrae esa información (Beltrán 1978: mapa 11; Utrilla 1982:221; Esteban 1990:334).

El único autor que aporta algo más de información sobre la o las piezas de Covairada es L. Caballero (Caballero y Argente 1975:143) que da dos referencias bibliográficas de J.M. Apellániz. Tampoco este investigador, en sus tablas tipológicas y en el recuento de las piezas, indica el tipo de t.s.g.t. del que se trata, si es gris o anaranjada, ni tampoco menciona el número de piezas recogidas, ni siquiera la forma o la decoración (Caballero y Argente 1975: fig.6).

En la primera cita bibliográfica de J.M. Apellániz (1974:298-312), a la que se refiere L. Caballero, no aparece mención alguna a una sigillata de este tipo. La segunda referencia (Apellániz 1973:89-97; fig.64c, 18-20) resulta también confusa. Por un lado, J.M. Apellániz (1973:91) no indica el tipo de pastas ni el color de las piezas que ilustra en su 
figura 64c; y, por otro, en los dibujos que presenta del nivel IA de Covairada no son muy clarificadores y los fragmentos cerámicos se asemejan más a la t.s.h.t.

\section{Cueva de Uraxpe III (Arechabaleta, Guipúzcoa)}

Este yacimiento en cueva cuenta con un importante nivel sellado de época tardorromana. Tan sólo lo conocemos por un breve resumen de la segunda campaña de excavaciones, dirigidas por M. Urteaga (VV.AA. 1986:48-50). Dentro de este nivel tardío se hallaron, por lo que sabemos, distintos fragmentos de t.s.g.t. correspondientes a las formas 1 y 18 de Rigoir (fig. 5,4 y fig.12,36).

\section{Cabo de Higuer (Fuenterrabía, Guipúzcoa)}

En este caso, se trata de un fondeadero que no aporta datos contextuales debido a la misma naturaleza del depósito. Pero sí, en cambio, aporta datos interesantes para comprender las relaciones comerciales atlánticas (Benito 1988:159), desde el punto de vista geográfico.

Las investigaciones de los últimos años pretenden recoger y estudiar el material procedente de este fondeadero, tanto el extraído durante las excavaciones arqueológicas como el que se encuentra disperso en distintas colecciones particulares (Benito 1990:119). Por lo que se refiere a la t.s.g.t. (Benito 1990:120 y 128) se localizaron varias piezas identificadas con las formas Rigoir 6 y 29 (fig.8,14; fig.13,40-41 y fig. 14,42-43).

\section{Peña Forua (Forua, Vizcaya)}

En el yacimiento de la cueva de Peña Forua, también conocida como Ginerradi o Urberuaga, se halló un nivel romano bajo-imperial que se ha fechado, de forma general, entre los siglos IV y v d.C. (Martínez y Unzueta 1988:61). Dentro de este nivel se localizaron varias piezas de t.s.g.t. de las formas Rigoir 1 (fig.5,5 y fig.6,6), 6a (fig.8,17), 6b (fig.9,18), 8 (fig.9,22), 16 (fig.11,32-33) y 18 (fig.12,35). En este caso se han localizado tanto producciones del taller atlántico como del languedociano, así como unos pequeños cuencos de imitación (fig.21,69-70).

El problema que presenta el denominado nivel bajoimperial de Peña Forua es que no se trata de un nivel cerrado ya que, junto a la t.s.g.t., se encuentran otras piezas de cronología alto-imperial, cuya presencia no ha sido considerada como significativa por sus excavadores, pero que sí es importante a la hora de fechar las importaciones de $t$.s.g.t. en Hispania, pues en Peña Forua sólo se han fechado por similitudes tipo- 
lógicas con los hallazos franceses y no por el contexto arqueológico en el que han sido localizadas.

\section{Navarra}

\section{Cueva de Abauntz (Arraiz)}

Los ejemplares de Abauntz que han sido fechados en la segunda mitad del siglo $\mathrm{v}$ d.C. por su excavadora, resultan problemáticos. Se trata de dos fragmentos decorados de bases que, en una primera publicación, fueron identificados con la forma 8 de Rigoir (Utrilla 1982:219) pero que podrían corresponder a las formas 1 o 4 de Rigoir (fig.10,2324); tampoco su adscripción al taller del Languedoc es tan clara, pues podrían proceder de un taller atlántico.

Los ejemplares de Abauntz se localizaron en el nivel A de la cueva, que corresponde a un estrato bastante alterado, con materiales de diversas épocas, desde el Magdaleniense hasta época romana bajoimperial.

\section{Pompaelo (Pamplona)}

La mayoría de las piezas de Pamplona proceden de niveles tardorromanos. M.A. Mezquiriz (1978:45) las dató, de forma general, entre los siglos v y vi d.C., conviviendo con algunas formas de t.s.h.t. como la forma 37 tardía.

Un problema que presenta el texto de M.A. Mezquiriz, para el caso que nos ocupa, es que no indica en la descripción de cada pieza de t.s.g.t. la correspondencia con la tipología de Rigoir. En cambio, las formas que indica de manera general - Rigoir 1, 8, 6a, 15a y 22-, a nuestro entender, no se corresponden del todo con las formas que presenta en su tabla IV; estas formas serían: Rigoir 1 (fig.7,8-9), 6a (fig.9,19), 6b (fig.9,20), variante de la forma 8 (fig.9,21), 15a (fig.10,25-26), 20 (fig.10,27-28) y 30 (fig.12,38).

En cuanto a la procedencia de estas piezas navarras, hay que señalar que ninguna pertenece al taller aquitano. Pompaelo se abastece de los talleres mediterráneos: languedociano y provenzal. 


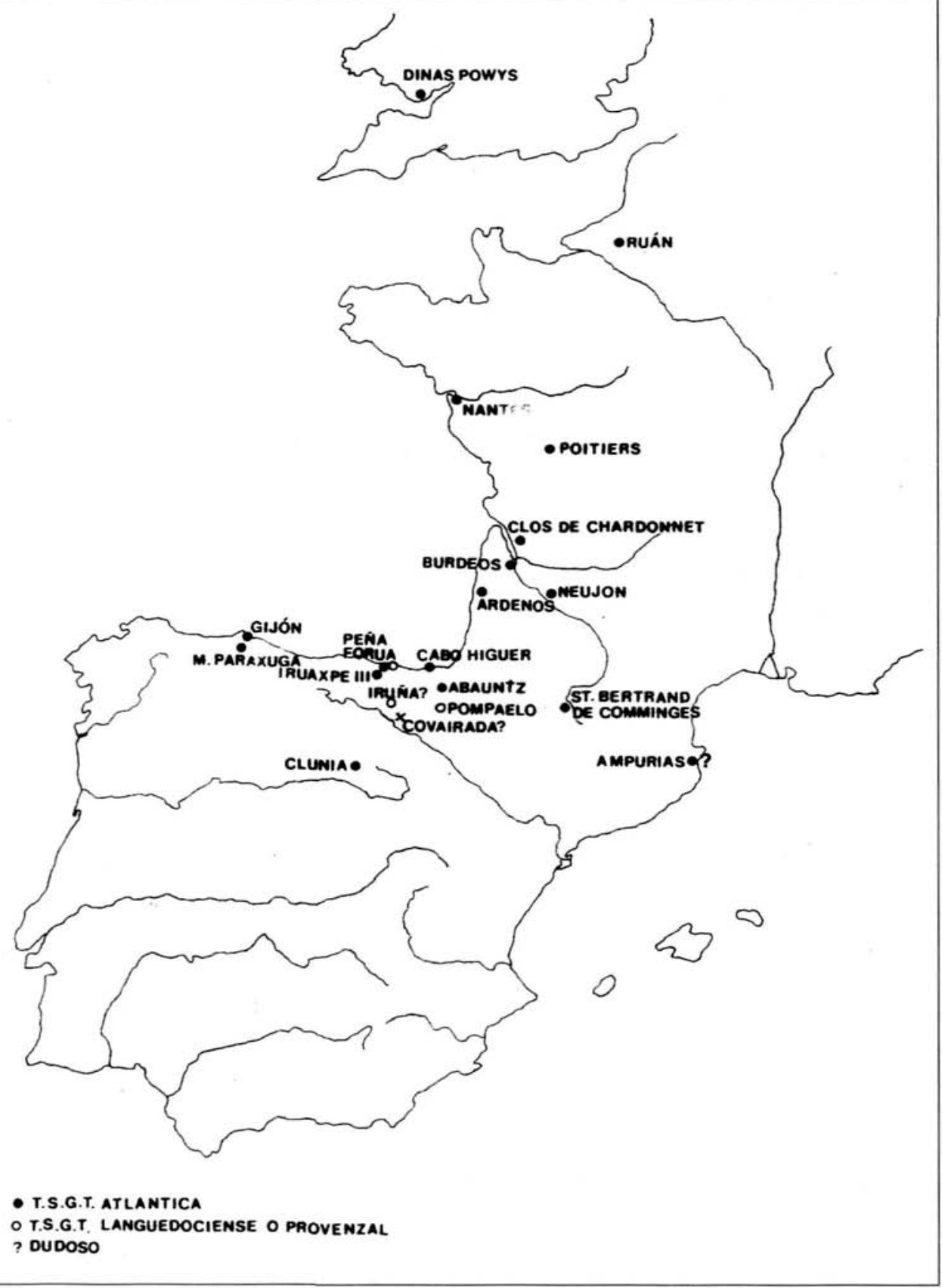

Figura 3. Yacimientos del norte de la Península Ibérica con hallazgos de t.s. gris gálica tardía (1992) 


\section{Castilla-León}

\section{Clunia (Burgos)}

Es el hallazgo de t.s.g.t. del taller atlántico más interior conocido. Aunque se ha hecho referencia en otras ocasiones a su existencia, la primera identificación como pieza del taller aquitano se debe a J. e Y. Rigoir (1971:38; fig.2).

La pieza en cuestión (fig.6,7) corresponde a la forma 1 de Rigoir. P. de Palol permitió a J. e Y. Rigoir el estudio de dicha pieza que, en aquel momento, aún no había sido publicada (Rigoir 1971:56, nota 1).

\section{ESTUDIO DE LAS PRODUCCIONES ATLÁNTICAS EN HISPANIA}

\section{Forma Rigoir 1}

Es una de las piezas mejor representadas del grupo atlántico; en Asturias hemos identificado cuatro ejemplares (fig.4,1-2 y fig.5,3). Esta forma corresponde a un plato o fuente abierta (Rigoir y Meffre 1973:223) de borde exvasado y base lisa o con un ligero repie o acanaladura bajo la base. En el origen de esta forma gala convergen varios tipos cerámicos como la t.s. sudgálica (formas Drag. 36 y 51) y la t.s.a. de los tipos C (forma 33 de Hayes) y D (formas 58 y 59 de Hayes).

Los hallazgos peninsulares de la forma 1 de Rigoir proceden de los talleres provenzales y languedocianos fechándose, de forma general, desde el último cuarto del siglo IV d.C. (Paz 1991:211). Sin embargo, los hallazgos de la zona cantábrica son, en su gran mayoría, del taller atlántico donde hemos diferenciado tres variantes, subdivididas en razón de la decoración de los bordes. Estas variedades son:

a) Variante de la forma Rigoir 1 con decoración a ruedecilla en el borde. El ejemplar más completo es el de Gijón (fig.4,1) que, además, conserva la decoración impresa a ruedecilla en el fondo dispuesta en círculo; es similar a un ejemplar bordelés (Rigoir 1968: lám.III, G-84) y está decorado con series de estampillas de palmetas dispuestas de forma radial en el fondo de la pieza (Rigoir y Meffre 1973: lám. XXI,2246). Se conocen otros ejemplos semejantes en Burdeos, en Saint Bertrand de Comminges (Alto Garona), en Ardenos cerca de Burdeos y en Poitiers (Rigoir y Meffre 1973: lám.I,2826, 4384, 3708, 3694 y lám.II,3344, respectivamente).

b) Variante de la forma Rigoir 1 con decoración incisa en el borde. Según Hayes (1972:402), las muescas en el borde derivan directamente de los modelos metálicos y no de la $t$.s.a. Estas incisiones las encontramos en ejemplares franceses (Rigoir y Meffre 1973: lám.I,4430) combinadas con decoración de ruedecilla, también en el borde, como el de Nantes con el borde algo más biselado (Rigoir 1968: lám.III,G; Rigoir y Meffre 1973: 


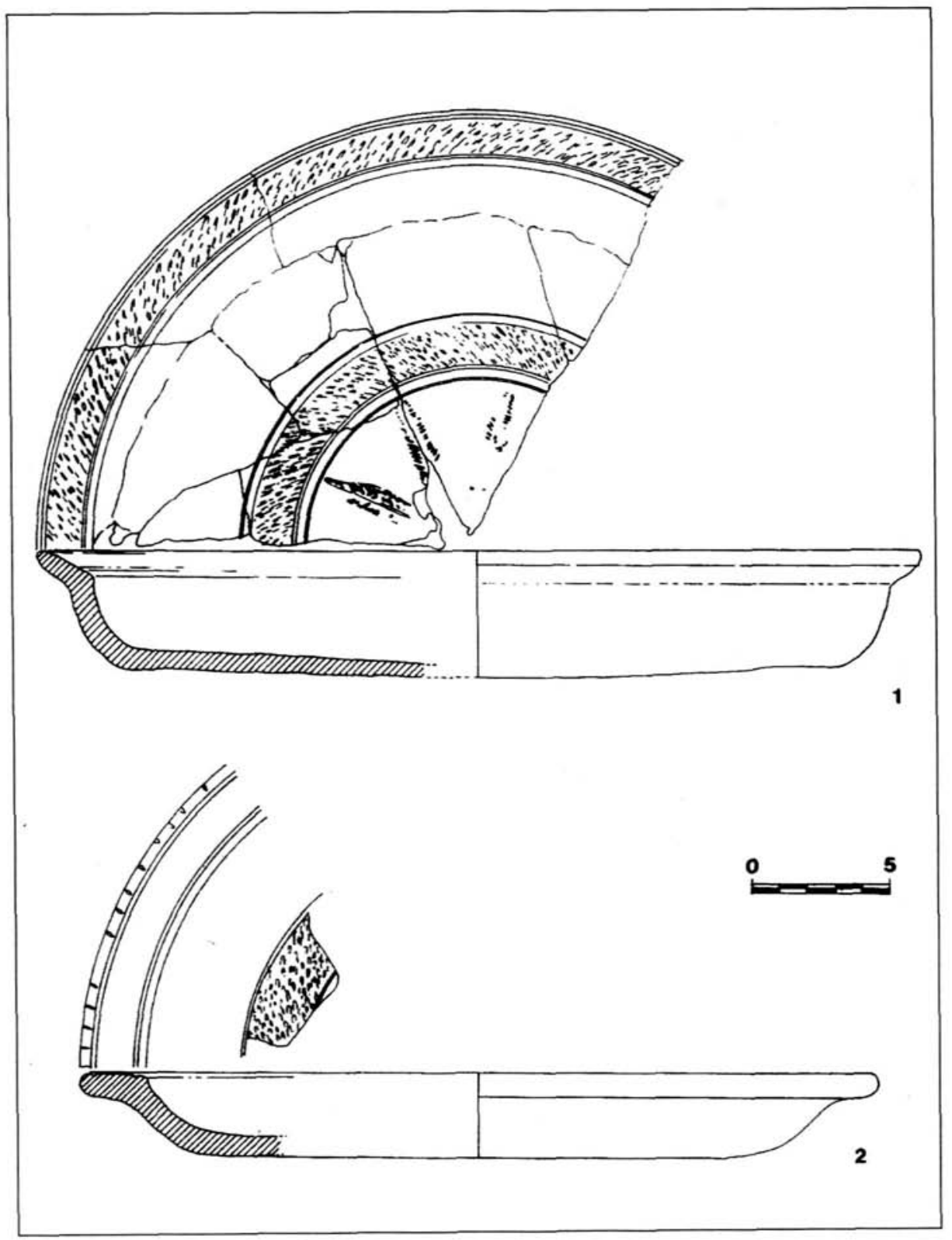

Figura 4. Platos de t.s.g.t. de la forma Rigoir 1 de Gijón 


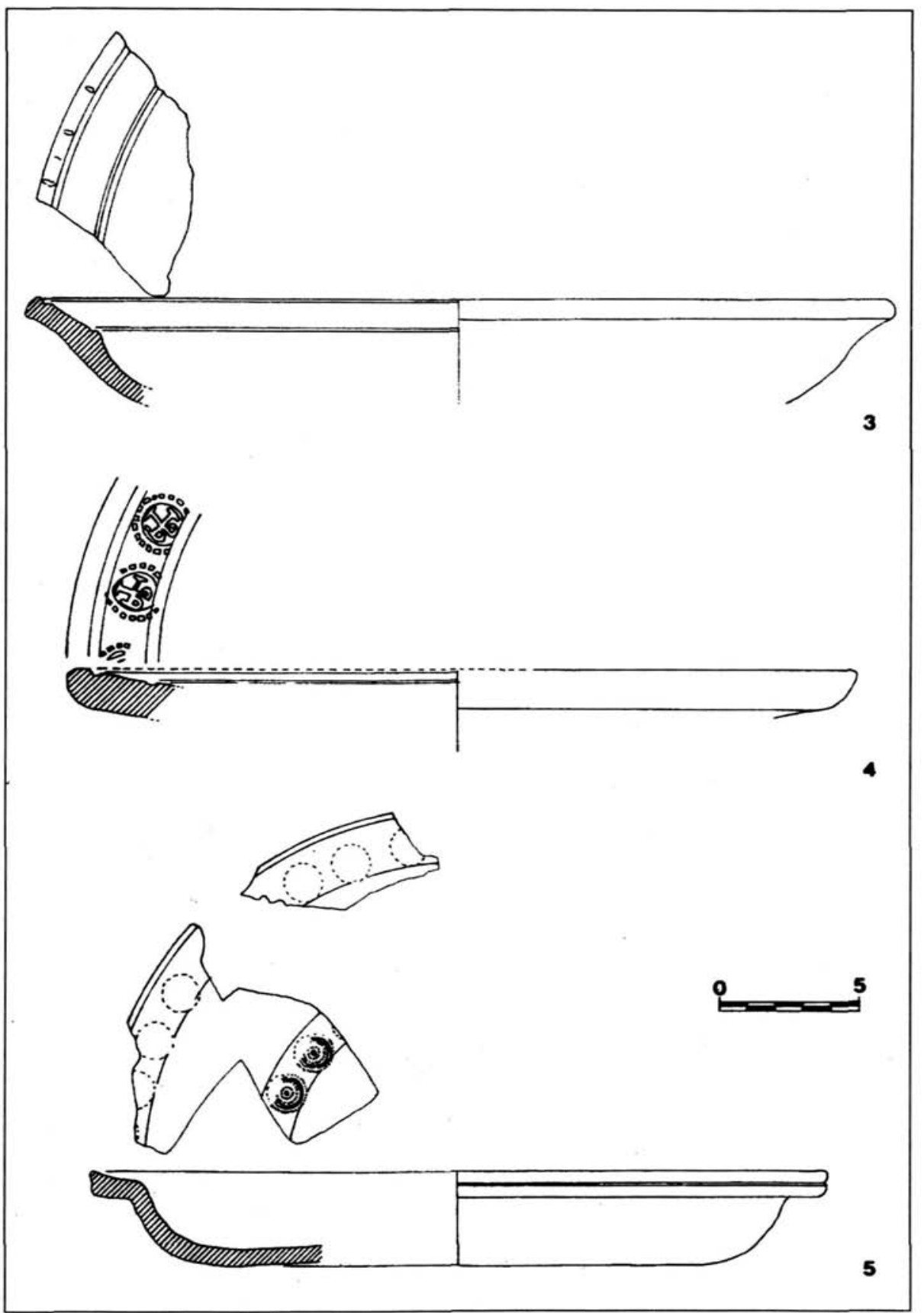

Figura 5. Platos de t.s.g.t. de la forma Rigoir $1: 3$ ) Murias de Paraxuga; 4) Iruaxpe III [VV.AA. 1986:49 $\sin$ indicación de escala]; 5) Peña Forua [según Martínez y Unzueta 1988: fig.18,63] 


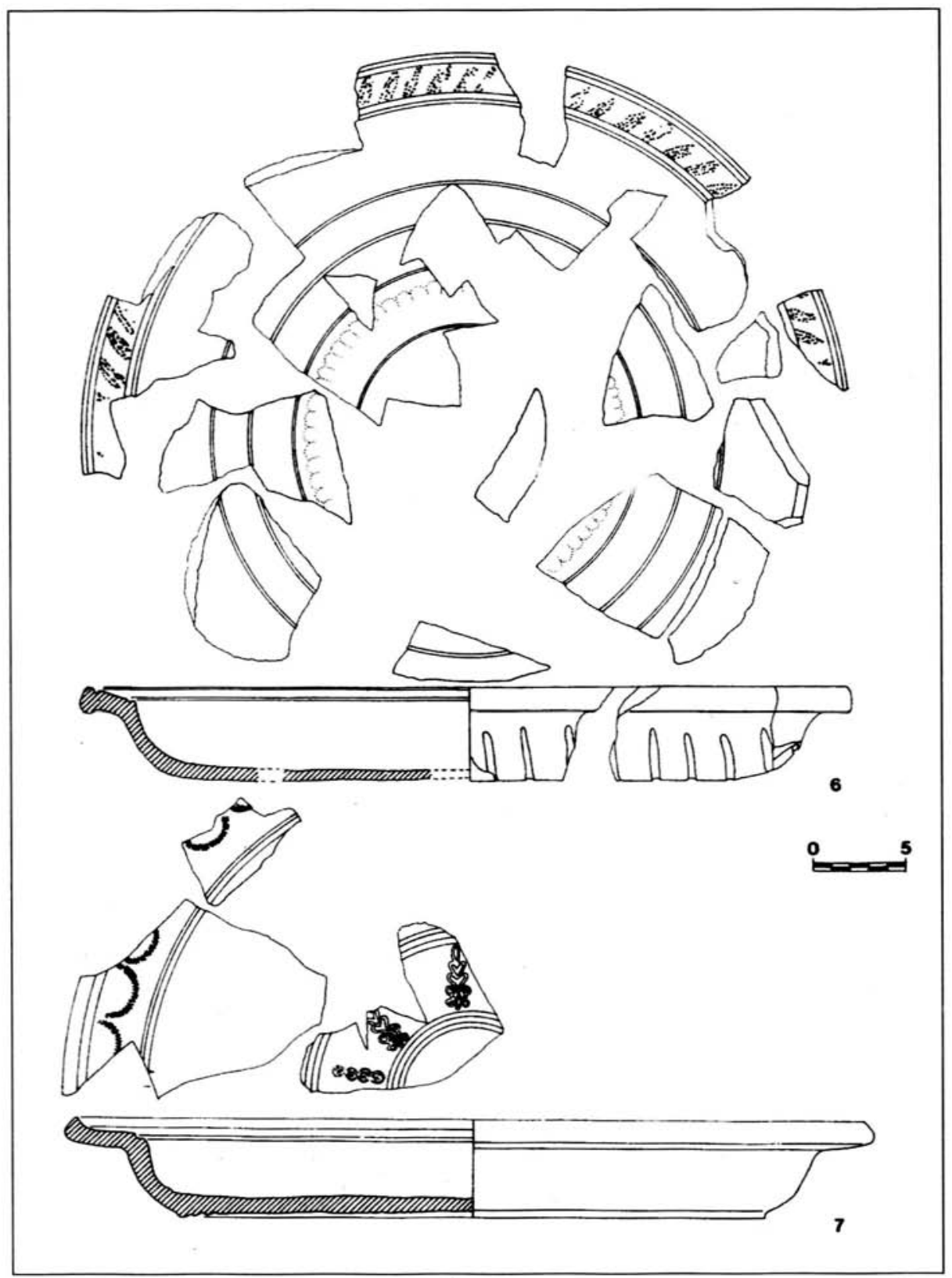

Figura 6. Platos de t.s.g.t. de la forma Rigoir 1: 6) Peǹa Forua [según Martínez y Unzueta 1988: fig.17,62]; 7) Clunia [según Rigoir 1971: fig.2 sin indicación de escala] 
lám.II,2927) o con estampillas como el de Neujon (Gironda) (Rigoir y Meffre 1973: lám.III,4406). Hay dos ejemplos asturianos cuya decoración a ruedecilla está bastante perdida: el de Gijón (fig.4,2) y el de Murias de Paraxuga (fig.5,3). Este último ha sido publicado en otras ocasiones (Requejo y Carrocera 1989:27, fig.1,10; Encinas y García 1992:132, fig.1,8) y fechado entre finales del siglo IV y el siglo $\mathrm{V}$ d.C. ${ }^{15}$. Esta pieza, en un primer momento, se identificó con una imitación hispánica pero algunos investigadores, como Requejo (1992:140), intuyeron su relación con el grupo aquitano: "...cuya panza, hemisférica, tiene tendencia a la forma cónica, típica de las producciones atlánticas.

c) Variante de la forma Rigoir 1 con decoración de estampillas en el borde. De los tres ejemplares de la zona norte española que se conocen sólo uno, el de Iruaxpe III, se halló en un nivel tardorromano y pudiera proceder del taller aquitano ya que el punzón (fig.5,4) de crismón es similar a otros de la producción atlántica (Rigoir y Meffre 1973: lám.XXV). Los ejemplares de Peña Forua son algo más difíciles de clasificar y fueron adjudicados a los talleres provenzal o languedociano; una de las piezas de Forua (fig.6,6) presenta unas estampillas de palmetas, cuyos paralelos franceses se localizaron tanto en los talleres languedociano (Rigoir 1968: lám.I. Pas de la Selle,2), provenzal (Rigoir 1968: lám.II. Marsella 4235) y atlántico (Rigoir y Meffre 1973: lám.III,3746-207 Ardenos); otra pieza de este mismo yacimiento presenta restos de unas estampillas circulares (fig.5,5) que, aunque, también se registran en el grupo provenzal (Rigoir 1968: lám.I, St. Blaise, 322), son más habituales en el grupo aquitano, con ejemplos en Burdeos, Neujon, Ardenos y Clos de Chardonnet (Rigoir y Meffre 1973: lám.IV,2747-2748, lám.III,4406, lám.IV,3738 y lám.II.4392, respectivamente). Quizá, por ello esta última pieza vasca pudiera proceder del grupo atlántico.

A esta forma de Rigoir 1 de la variante c se pueden anadir los ejemplares de Pompaelo (fig.7,8-9) (Mezquiriz 1978:45) aunque resulta muy difícil determinar su origen pues M.A. Mezquiriz no lo menciona en su texto. Sin embargo, parecen datarse entre los siglos v y vi d.C. También puede incluirse el plato de Clunia (fig.6,7) con estampillas en el borde aunque, en este caso, se trata de series de punzones de arquitos (Rigoir 1971: fig.2); una particularidad de esta pieza identificada como atlántica, es un punzón relacionado con otros motivos norteafricanos de la t.s.a. del tipo D (Rigoir 1971:56).

${ }^{15}$ En un artículo anterior (Fdez Ochoa, García y Uscatescu 1992:126) recogíamos la noticia de la existencia de esta pieza cuya fabricación, E. Carrocera y O. Requejo (1989:27) adjudicaban a un taller hispánico (fig.5,3). No obstante, ya en ese trabajo (Fdez Ochoa, García y Uscatescu 1992: nota 19) sugeriamos un origen atlántico para estas piezas asturianas. Actualmente, y tras el estudio directo de las dos piezas de Paraxuga (fig.5,3 y fig.7,13) en el Museo Arqueológico de Oviedo, no tenemos ninguna duda al afirmar que ambas (formas Rigoir 1 y 4) pertenecen a la producción atlántica de t.s.g.t. Los ejemplares de Paraxuga son idénticos en pastas, acabados y formas a las piezas gijonesas, con perfiles redondeados, de sección gruesa, pastas muy depuradas, engobe de tacto suave, negruzco y delgado que se pierde con facilidad, pero que se mantiene en las acanaladuras y en las impresiones a ruedecilla. 


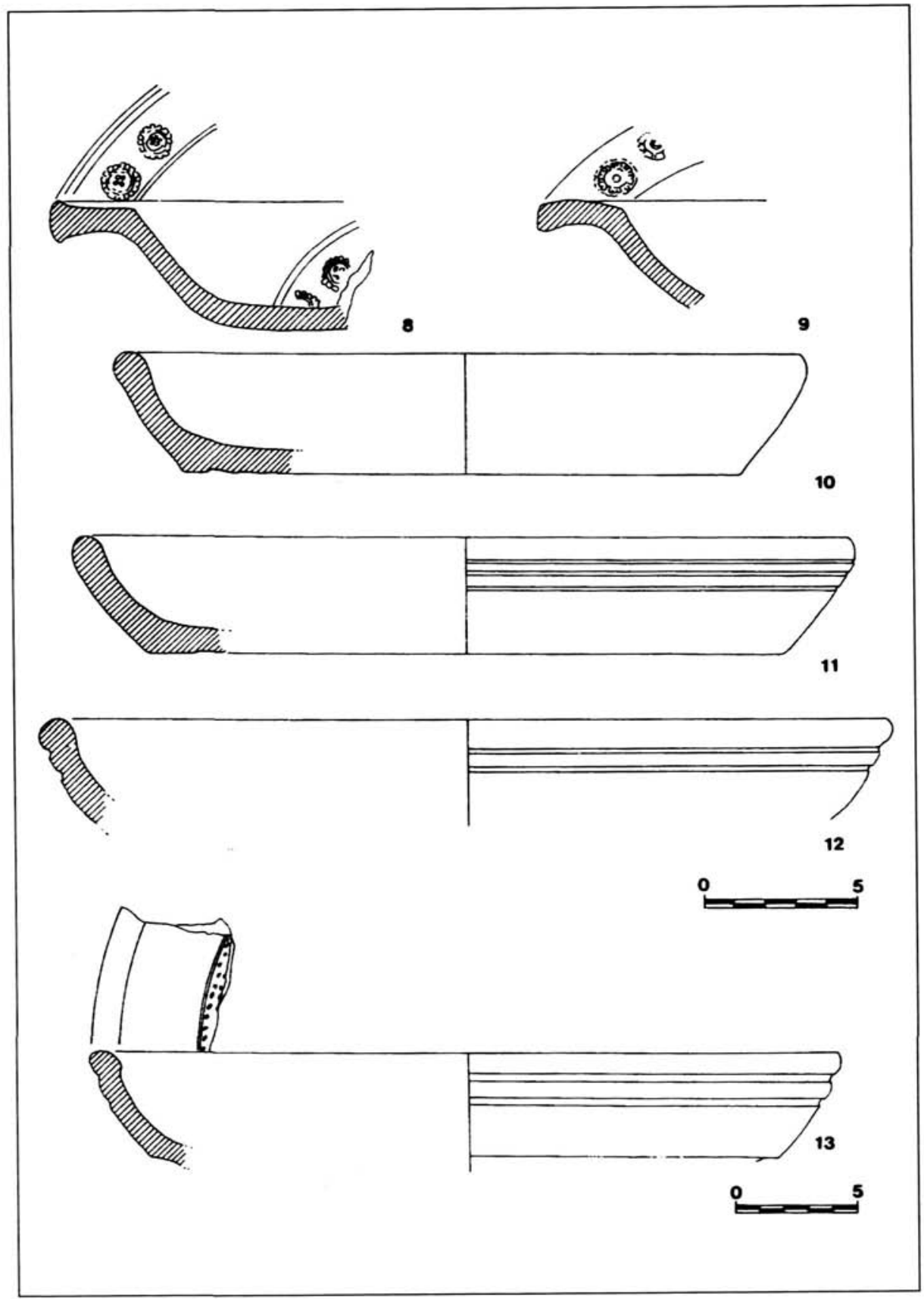

Figura 7. Platos de t.s.g.t. de la forma Rigoir 1: 8-9) Pompaelo [según Mezquiriz 1978: fig.31.9-10]. Forma Rigoir 4: 10-12) Gijón: 13) Murias de Paraxuga 


\section{Forma Rigoir 4}

Junto con la anterior, es una de las formas más abundantes en el taller atlántico. Parece derivar de la forma 9 de Lamboglia de t.s. narbonense o t.s. clara B (Rigoir 1968:202).

De este plato o fuente, de fondo plano y pared en forma de segmento de círculo, se conocen dos versiones, una lisa y otra caracterizada por la existencia de una o más acanaladuras horizontales en el exterior de la pared.

De la versión lisa existen dos ejemplares hallados en las excavaciones de las termas de Gijón, uno de reciente descubrimiento (fig.7,10) y otro exhumado a principios de siglo por C. Alvargonzález y publicado por este mismo erudito que, aunque, lo relacionó con producciones modernas del alfar de Faro, tras la revisión que de esta obra publicamos (Fdez Ochoa, García y Uscatescu 1992:126, fig.17,43) se podría identificar, sin problemas, con una t.s.g.t. de la forma Rigoir 4. Entre otros paralelos lisos destacan los de Saint Bertrand de Comminges (Rigoir y Meffre 1973: lám.V,3755, 3783 y 2844).

En Gijón se han hallado dos piezas de la versión con acanaladuras (fig.7,11-12), en Murias de Paraxuga hay otro ejemplar (fig. 7,13$)^{16}$ que, como ya indicamos, fue definido erróneamente como una imitación de t.s.h.t. paleocristiana (Carrocera y Requejo 1989:26; Encinas y García 1992:132; Requejo 1992:140). Fuera de Hispania, se conocen los ejemplares de Poitiers (Rigoir 1968: lám.VII, G-LXVIII), Ruán (Rigoir 1968: G-167), Burdeos y Saint Bertrand de Comminges (Rigoir y Meffre 1973: lám.V,2763, 2815 y 3712, respectivamente) entre otros muchos.

\section{Forma Rigoir 6}

Este pequeño cuenco, según J. Rigoir (1968:203), deriva de la forma 17 de Hayes de t.s.a. del tipo C. Esta forma está ausente del corpus gijonés. En el fondeadero del cabo de Higuer se localizó una copa asimilable a la forma 6 de Rigoir (fig.8,14) (Benito 1990:120) con decoración de "palmitas" encuadradas entre dos acanaladuras y una serie de fragmentos (fig.8,15-16) también identificados con esta misma forma. No creemos que haya ninguna duda en su adjudicación al taller atlántico ${ }^{17}$. No obstante, A.M. Benito (1990:129) indica la existencia de producciones hispánicas pero adscribe con total seguridad las piezas de Higuer a los centros gálicos, señalando las semejanzas con los perfiles languedocianos y la decoración de tipo provenzal, aunque observa que, por su posición geográfica, es más lógico pensar en un origen atlántico que sudgálico para estas piezas vascas.

\footnotetext{
16 Vid. nota 14 .

17 Esta pequeña copa sólo la conocemos por el dibujo y las descripciones publicadas (Benito 1990). No obstante, su forma y decoración coinciden con las del grupo atlántico.
} 


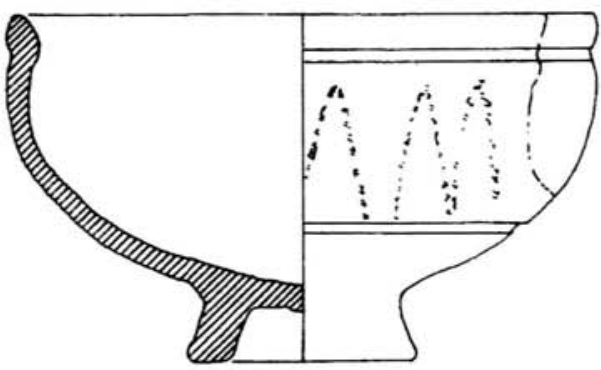

14

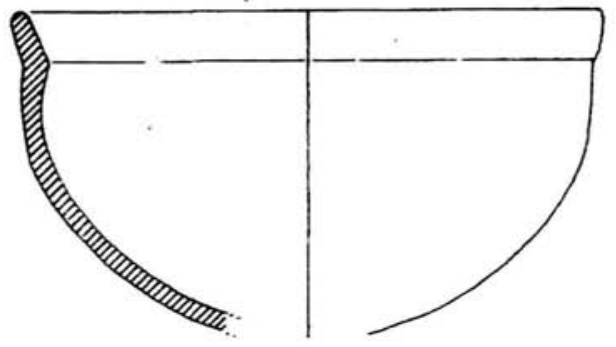

15
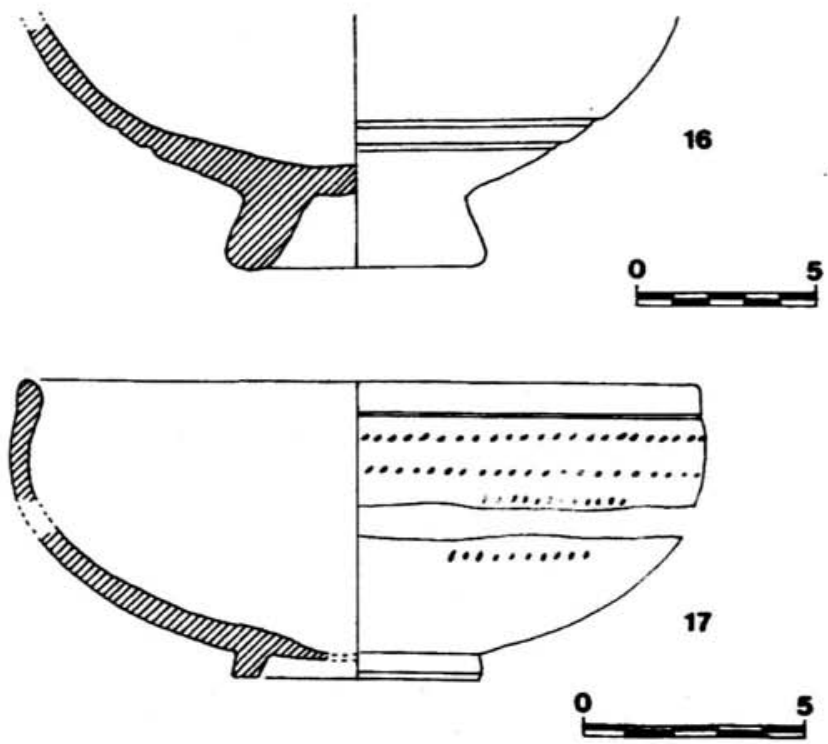

Figura 8. Cuencos de t.s.g.t. de la forma Rigoir 6: 14-16) cabo de Higuer [según Benito 1990: lám.I,1-2 y lám.II,6]; 17) Peña Forua [según Martínez y Unzueta 1988: fig. 20,66] 
J. Rigoir (1968:203) diferenció dos variantes. La 6a es un cuenco hemisférico que, en el grupo atlántico, está decorado con burilado como el ejemplar de Peña Forua (fig.8,17) fechado desde finales del siglo IV al siglo v d.C. o el de Pompaelo (fig.9,19) de probable filiación languedociana.

Por otra parte, la forma $6 \mathrm{~b}$ caracterizada por una proyección del borde hacia el interior, se ha localizado en Peña Forua con decoración mixta burilada y estampada de columnitas rematadas con pequeños círculos (fig.9,18); este motivo es similar a uno hallado en Rosas (Rigoir 1971:63, n. ${ }^{\circ}$ 746) que no puede considerarse como producto aquitano, sino que se debe asociar a los cuencos del grupo languedociano. Otra pieza de Pompaelo (fig.9,20) corresponde a la variante $6 \mathrm{~b}$ de Rigoir y, podría relacionarse con una producción provenzal ya que su forma recuerda a la publicada por Rigoir (1968: lám.IX, Marsella III.2.43). Los punzones que decoran este cuenco navarro son similares a los otros hallados en la Península Ibérica, concretamente a los de Rosas y Ampurias (Rigoir 1971: $\mathrm{n}^{\circ} 747$ y n. $^{\circ} 770$ respectivamente).

\section{Forma Rigoir 8}

Este plato, según Rigoir (1968:203), deriva de las formas 61B y 104/105 de Hayes de t.s.a. D.

En el norte de España sólo conocemos dos ejemplares que puedan ser adscritos a esta forma y, al igual que la forma anterior, sólo se conocen por el dibujo y la descripción publicados. Se trata de un ejemplar de Peña Forua (fig.9,22) y uno de Pompaelo (fig.9,21) que pudiera resultar una variante de esta forma, cercana a la forma 4 de Rigoir. En Marsella existe un ejemplar semejante (Rigoir 1968: lám.XI, Marsella, 11.1.1o) y sus estampillas recuerdan a las halladas sobre un plato tarraconense (Rigoir 1971: . $^{\circ} 579$ ).

Más dudosos son los dos fragmentos de base (fig.10,23-24) de la cueva de Abauntz que fueron asociados a esta forma ${ }^{18}$ y se fechan, por la similitud de la forma 8 de Rigoir con la forma Hayes 61B de t.s.a. D, en la segunda mitad del siglo v d.C. La atribución de estos fragmentos a cualquier grupo gálico resulta problemática. Inicialmente, fueron adjudicados al taller languedociano por J. Paz (Utrilla 1982:219) pero también se planteó su posible origen atlántico puesto que el yacimiento de Abauntz se localiza en la clásica vía de penetración desde Aquitania. Así mismo, la estampilla de arquitos con motivo vegetal del palmetas (fig.10,24) (Rigoir 1981:186) y, sobre todo, el círculo impreso a ruedecilla que rodea estos punzones es propio de los talleres aquitanos ${ }^{19}$.

18 Estos fragmentos también podrían pertenecer a las formas 1 o 4 de Rigoir.

19 Algunas piezas del grupo languedociano también se caracterizan por este círculo a ruedecilla; la diferencia fundamental estriba en la calidad de la impresión, más recta y precisa en el grupo atlántico, es decir, un burilado (Rigoir y Rivet 1985:89). En este caso sólo un nuevo examen de la pieza de Abauntz podría determinar su verdadero origen. 


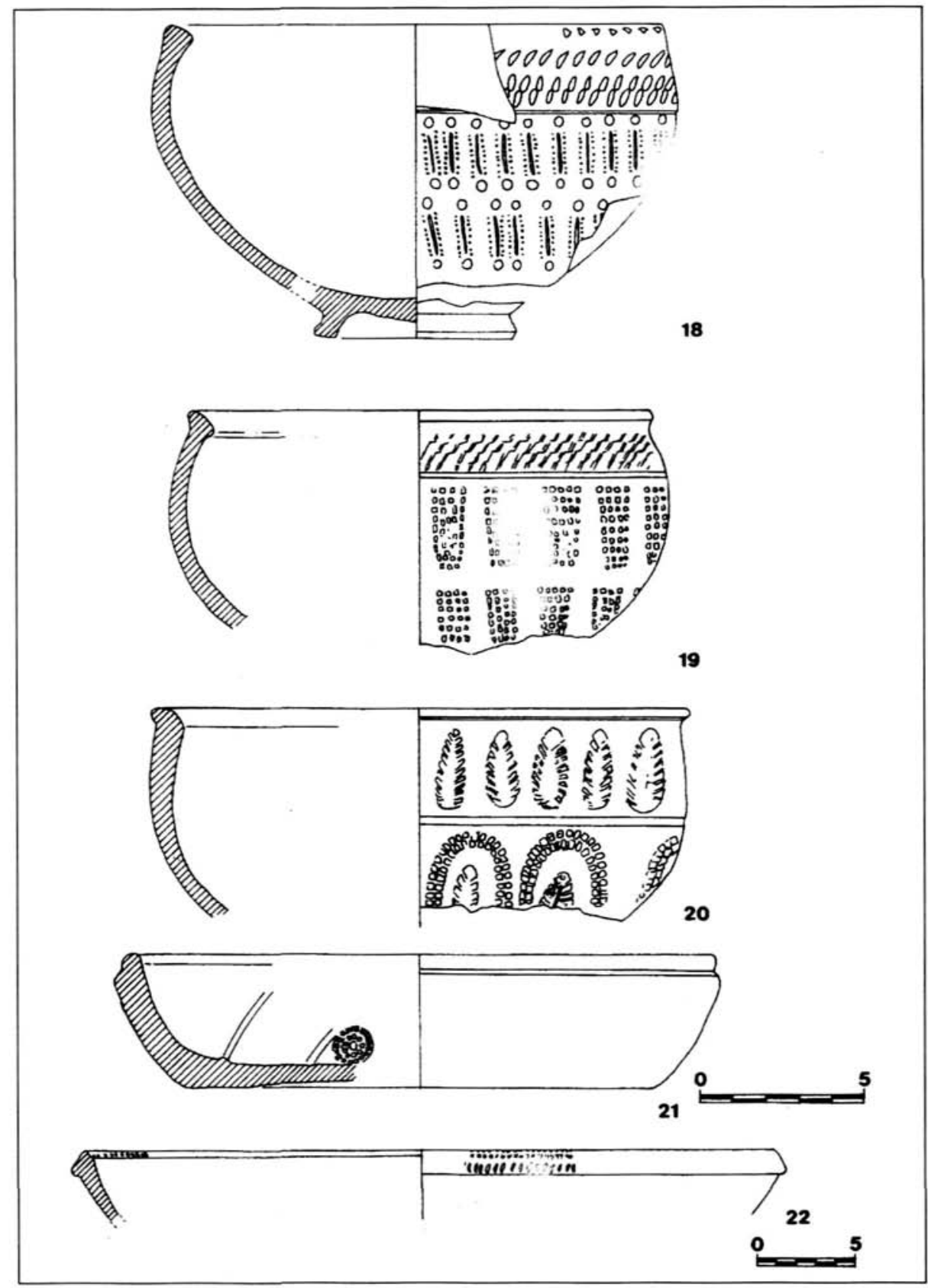

Figura 9. Cuencos de t.s.g.t. de la forma Rigoir 6: 18) Peña Forua [según Martínez y Unzueta 1988: fig.21,69]; 19-20) Pompaelo [según Mezquiriz 1978: fig.31,1-2]. Platos de t.s.g.t. de la forma Rigoir 8: 21) Pompaelo [según Mezquiriz 1978: fig.31,6]; 22) Peña Forua [según Martínez y Unzueta 1988: fig.19,64]. 


\section{Forma Rigoir 15}

Estos cuencos carenados (Rigoir 1968:205) presentan una amplia variedad de tamaños; son más abundantes en la producción languedociana.

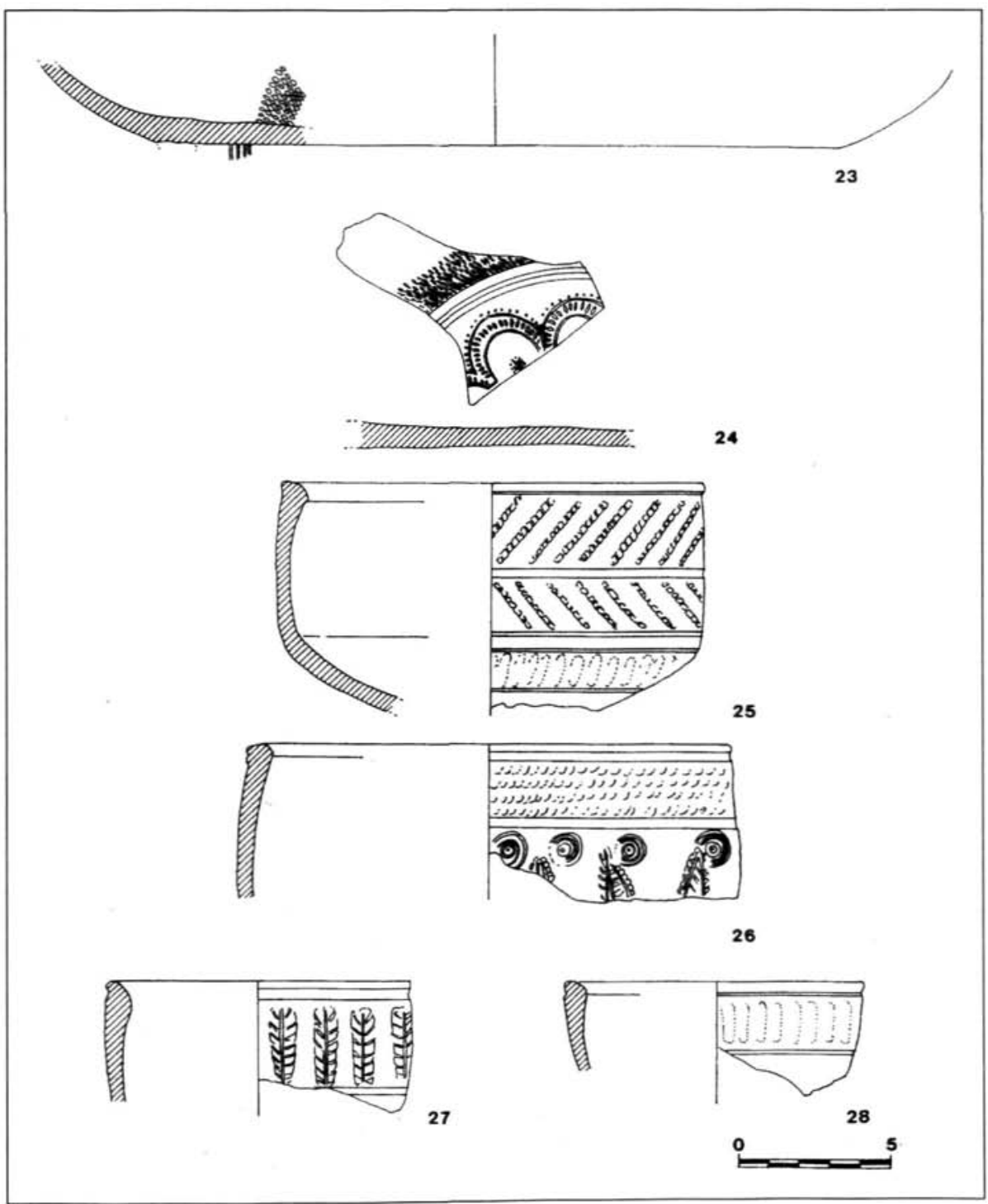

Figura 10. Fragmentos de t.s.g.t. decorados: 23-24) Abauntz [según Utrilla 1982: fig.8,1-2]; Cuencos de t.s.g.t. de la forma Rigoir 15a: 25-26) Pompaelo [según Mezquiriz 1978: fig.31,3-4]. Forma Rigoir 20: 27-28) Pompaelo [según Mezquiriz 1978: fig.31,5 y 7] 
Las piezas de Pompaelo, posiblemente, de producción languedociana pertenecen a la variante 15 a de Rigoir. El más completo (fig.10,25) presenta una simple decoración dispuesta en tres frisos. El otro ejemplar (fig.10,26) tiene un decoración más complicada, combinando motivos de ruedecilla, en la parte superior, con punzones de pequeños círculos concéntricos y palmetas, cuya adscripción al repertorio de J. e Y. Rigoir es difícil por la calidad del dibujo y por el estado fragmentario de las estampillas.

\section{Forma Rigoir 16}

Cuenco carenado (Rigoir 1968:205) del grupo atlántico, donde no es tan común como las formas 1 y 4 pero, sin embargo, es la forma más importada. Es más corriente en Provenza y en Narbona (Rigoir y Meffre 1973:224).

A este grupo se adscriben unos cuencos gijoneses (fig.11,29-31). La mayor parte está decorada con ruedecilla. En uno de los cuencos se advierte un tipo de impresión (fig.11,30) que, pese al mal estado de conservación de la pieza ${ }^{20}$, recuerda al tipo de ruedecilla definido (Rigoir y Meffre 1973:244, fig.11,3699) como "múltiples depresiones" realizadas por varias ruedecillas o varios pasos de ruedecilla; resulta una técnica indeterminada, pero su existencia en Gijón reafirma la hipótesis del directo abastecimiento de esta ciudad asturiana de los alfares de litoral atlántico galo. A las tres piezas gijonesas hemos de sumar dos de Peña Forua (fig.11,32-33). El ejemplar más septentrional de esta forma procede de Dinas Powys (Gales); otros ejemplos franceses son los de Poitiers, Burdeos o Ardenos (Rigoir y Meffre 1973: lám.XV,3313, 3345, 2800-2801 y 3736, respectivamente).

\section{Forma Rigoir 18}

La forma de este cuenco recibe dos tipos de influjos galos (Rigoir 1968:207); por un lado, deriva de la forma Drag. 37 de t.s. sudgálica y, por otro, de las formas $2 / 37$ y 2 de Lamboglia de la t.s. lucente y t.s. narbonense o clara B, respectivamente. Dentro del repertorio morfológico atlántico es una forma muy característica. J. Rigoir (1968:185) en un principio indicó que esta forma, junto a la forma 3, estaba ausente del repertorio atlántico. Sin embargo, en ulteriores publicaciones corrigió esta afirmación, señalando que estaba presente pero en menor medida (Rigoir y Meffre 1973:222).

En Gijón hay un pequeño fragmento (fig.12,34) que pudiera corresponder a esta forma; es similar, pero no idéntico, a los publicados por J. Rigoir, por lo que esta clasificación no es, de ningún modo, definitiva y tiene un carácter preliminar. Los ejemplares más complet os son el de Peña Forua con decoración burilada (fig.12,35) semejante a la de una pieza de Saint Bertrand de Comminges (Rigoir y Meffre 1973: lám.XVI,3704) y el de

20 El engobe de este ejemplar se encuentra totalmente perdido y la superficie de la pieza está bastante alterada, pero no lo suficiente como para no poder apreciar su decoración impresa a ruedecilla. 


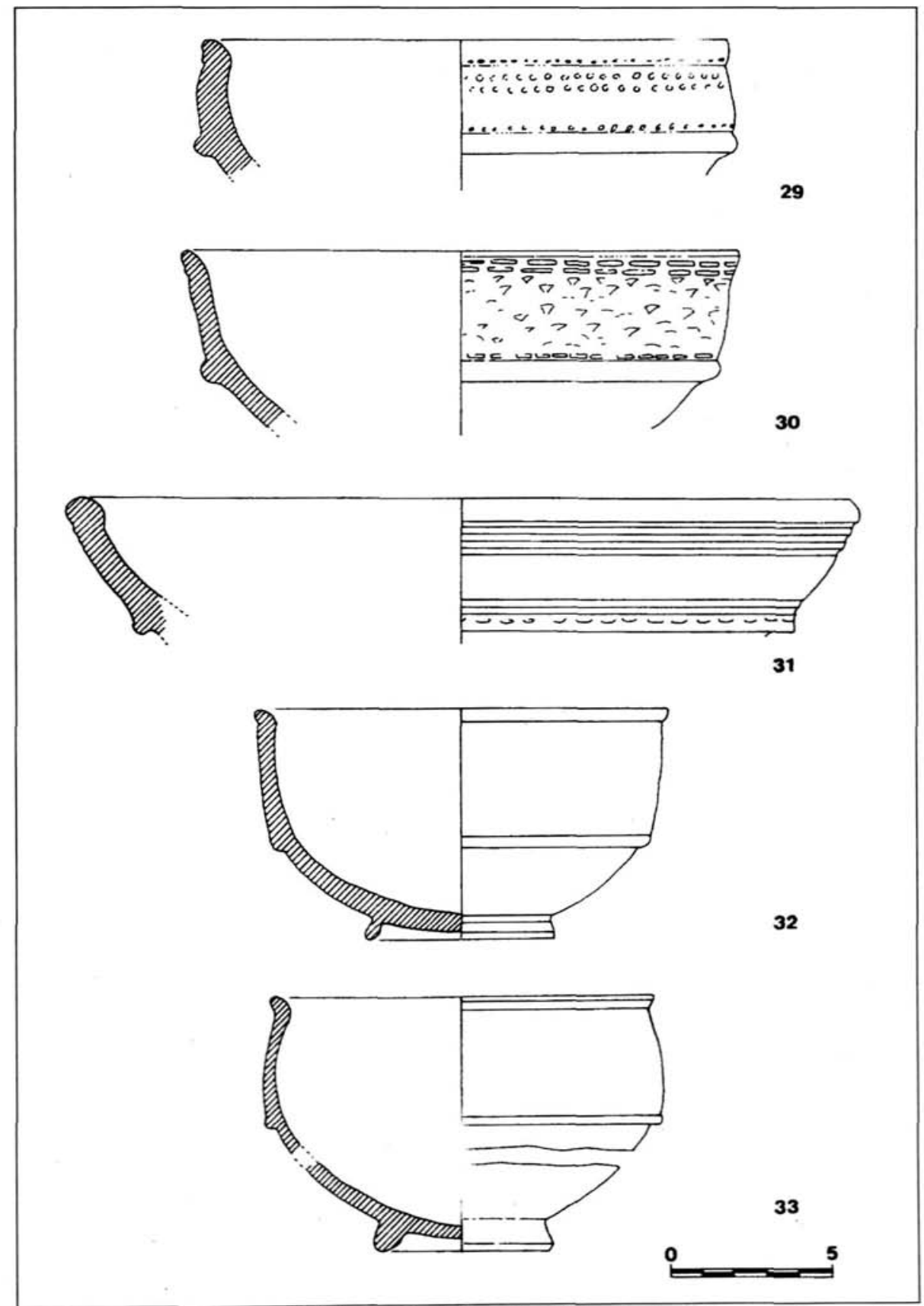

Figura 11. Cuencos de t.s.g.t. de la forma Rigoir 16: 29-31) Gijón; 32-33) Peña Forua [según Martinez y Unzueta 1988: fig.20,67-68] 


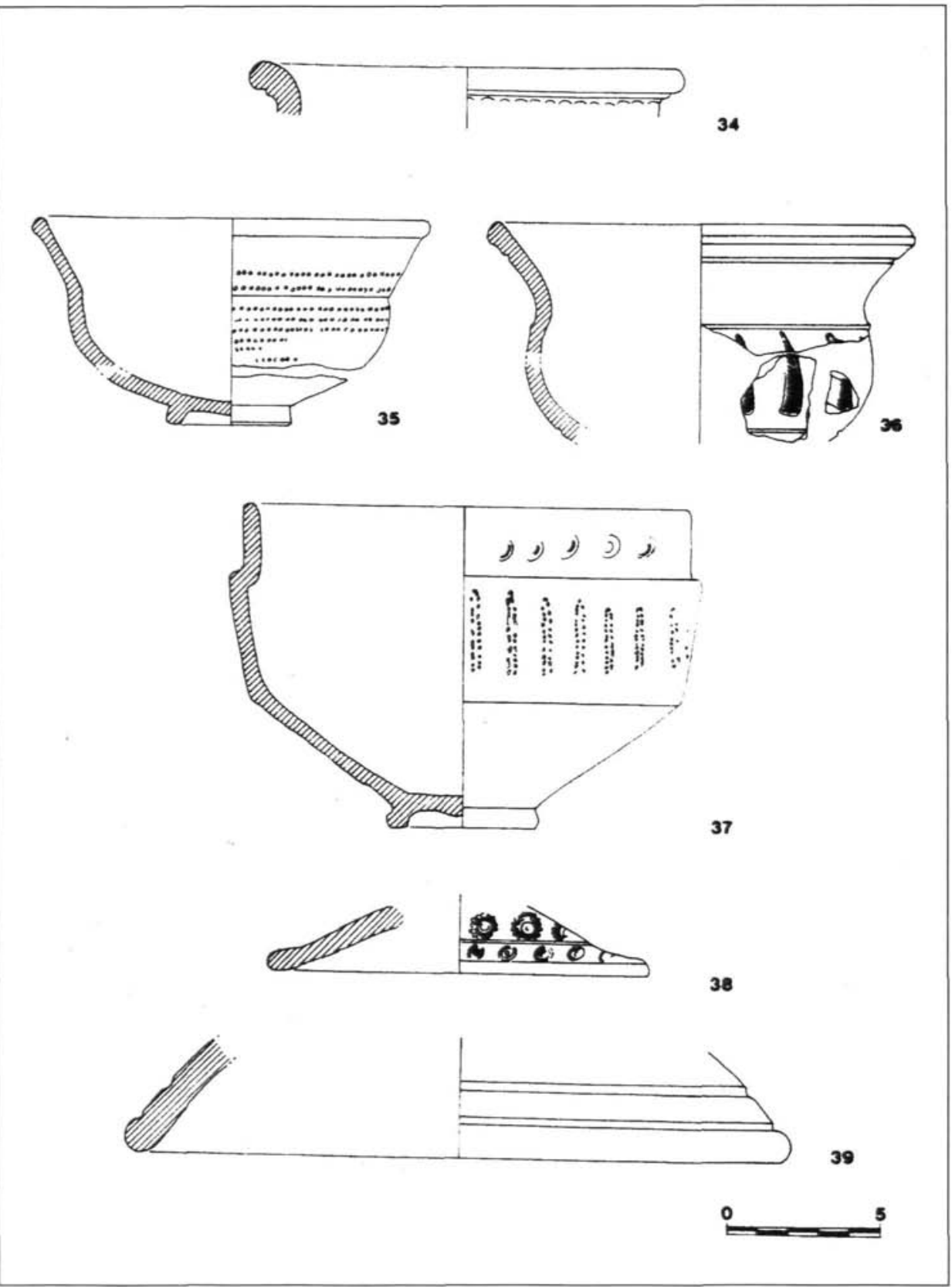

Figura 12. Cuencos de t.s.g.t. de la forma Rigoir 18: 34) Gijón; 35) Peña Forua (según Martínez y Unzueta 1988: fig.19.65]; 36) Iruaxpe III [VV.AA. 1986:49 sin indicación de escala]; 37) Iruña [Nieto 1958: fig.107]. Tapaderas de t.s.g.t. de la forma Rigoir 30: 38) Pompaelo [según Mezquiriz 1978: fig.31,8]; 39) Gijón 
Iruaxpe III (fig.12,36); la forma y decoración de palmetas estampadas (VV.AA. 1981:6, lám.XI,83) de este último recuerda al de una pieza gala (Rigoir y Meffre 1973: lám.XVI,4414) de la producción atlántica, por lo que este cuenco podría ser del grupo aquitano.

La más problemática es la pieza de Iruña (fig.12,37). L. Caballero (Caballero y Argente 1975:143, fig.6) indicó su pertenencia a la forma 18 de Rigoir. Pero, como hemos indicado anteriormente, la forma general de este vaso troncocónico no encaja perfectamente con el perfil globular de los cuencos de esta forma francesa. Al no haber estudiado la pieza directamente no estamos en condiciones de poder afirmar si se trata de una imitación hispánica de t.s.h.t. o si es una variante, más angular, de la forma 18 de Rigoir. Decorativamente, y en caso de confirmarse su origen francés, esta pieza alavesa se adscribiría al estilo ornamental languedociano.

\section{Forma Rigoir 20}

Esta forma corresponde a una copa cilíndrica (Rigoir 1968:207). En el norte peninsular sólo hemos localizado dos piezas provenzales halladas en Pompaelo (fig.10,27-28). Ciertamente, la adscripción de estos bordes a la forma 20 es preliminar puesto que, por su tamaño, no podemos saber con seguridad si se trata de este tipo de copas que se caracterizan por una serie de molduras en el exterior, y las piezas de Pamplona no las conserva por su pequeño tamaño. No sabemos si M.A. Mezquiriz (1978:45, fig.31,5 y 7) se refiere a estas piezas cuando menciona la existencia de la forma 22 de Rigoir dentro del repertorio de Pompaelo.

\section{Forma Rigoir 29}

Se incluye en la categoría de la cerámica de cocina o de uso común. Corresponde, formalmente, a los morteros con listel (Rigoir 1968:209) que se caracterizan por la ausencia de engobe y la presencia de granos de basalto en el fondo, para facilitar el triturado.

Este tipo de mortero no se ha identificado en el conjunto asturiano. En cambio, en el fondeadero del cabo de Higuer (fig.13,40-41 y fig.14,42-43) se recogieron cuatro piezas; alguna de ellas presenta las típicas acanaladuras o ranuras exteriores de los morteros bordeleses (Rigoir 1968:209, lám.XX,71; Rigoir y Meffre 1973: lám.XVII,2770 y 2785). Los morteros gálicos del cabo de Higuer no son los únicos ejemplares producto de una importación marítima ya que, también, se conoce otro hallado en Dinas Powys, en Gales (Rigoir y Meffre 1973:215).

\section{Forma Rigoir 30}

Son pequeñas tapaderas cónicas. Las del grupo atlántico suelen ir decoradas con una o varias ranuras o acanaladuras en el exterior, como alguna pieza de Burdeos (Rigoir 


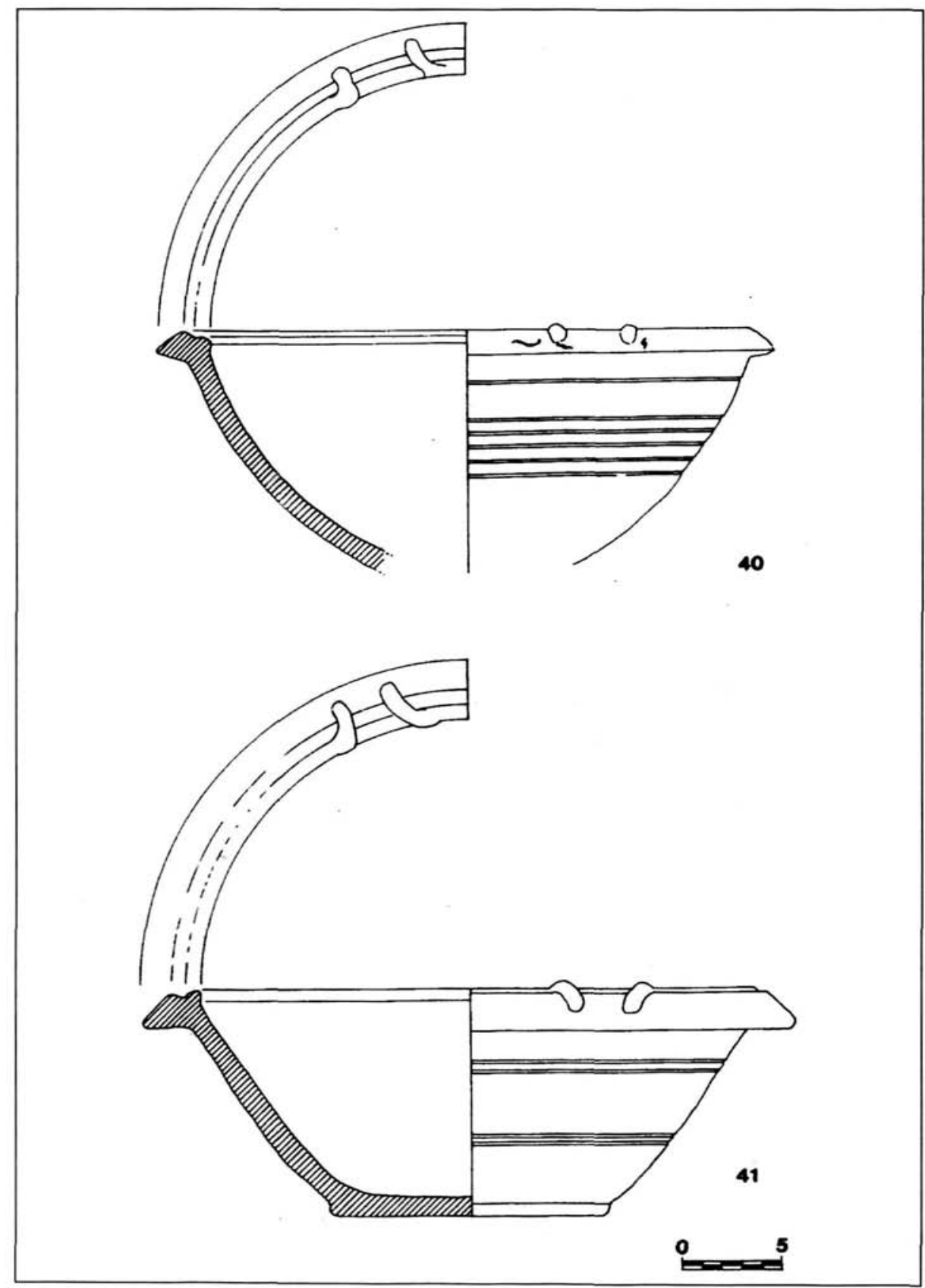

Figura 13. Morteros de t.s.g.t. de la forma Rigoir 29 del cabo de Higuer [según Benito 1990: lám. V y VI] 


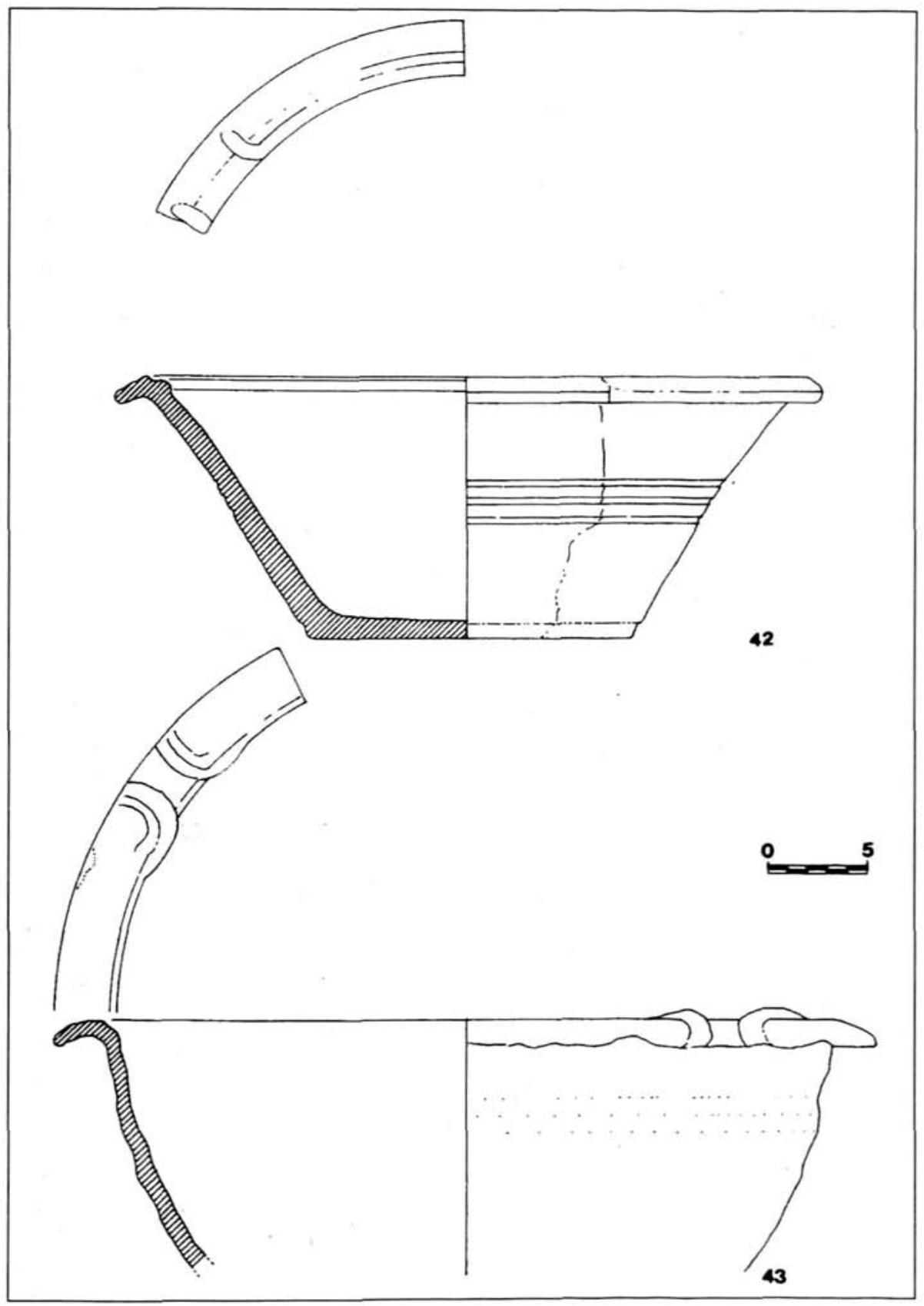

Figura 14. Morteros de t.s.g.t. de la forma Rigoir 29 del cabo de Higuer [según Benito 1990: lám. VI y III] 
1968:209, lám.VIII,G-40; Rigoir y Meffre 1973: lám.XVII,2766-2767). En Gijón sólo se ha identificado una pieza con estas características (fig.12,39) del taller atlántico. Mientras que la pieza de Pompaelo (fig.12,38) con sus estampillas de círculos concéntricos, podría proceder del taller provenzal (Rigoir 1968: lám.VIII, forma 30, Aix 1o).

\section{BASES Y FRAGMENTOS DECORADOS}

Las decoraciones estampadas de bases y fragmentos indeterminados se pueden dividir en tres tipos: figuradas, vegetales y geométricas.

\section{Decoraciones figuradas}

La base hallada en Gijón está decorada con varios punzones (fig.15,44). El motivo central es el de un ciervo ${ }^{21}$ rodeado por una palmeta y una roseta (Rigoir y Meffre 1973: lám.XXI,2175 y lám.XIX,2529, respectivamente). Este motivo central aparece rodeado por un círculo impreso a ruedecilla. Dentro del corpus atlántico el motivo de cérvidos es muy corriente, suele ser de un tamaño mayor que los narbonenses o provenzales, donde sólo aparece de forma esporádica (Rigoir y Meffre 1973:248) e ir acompañado por otros motivos: palmas, cruces, estrellas, soles, otros animales e, incluso, representaciones humanas esquemáticas, cuyo significado no es muy claro (Rigoir 1981:182).

\section{Decoraciones vegetales}

En Gijón, aparte el plato de la forma Rigoir 1 (fig.4,1), existe un fragmento de base (fig.15,45) que, quizá, pudiera pertenecer a esta misma forma. La base está decorada a ruedecilla impresa y con series de palmetas estampadas dispuestas en forma radial (Rigoir y Meffre 1973: lám.XXI,2175 y 2204 y lám.XXII,2262).

\section{Decoraciones geométricas}

En las termas gijonesas dos son los fragmentos que presentan decoración estampada de círculos. Uno de ellos (fig.15,46) presenta la superficie bastante alterada, sin engobe, pero aún se advierten las series de círculos dispuestos alrededor de uno central de mayor tamaño. El otro fragmento, también de base (fig.16,47), presenta un círculo

\footnotetext{
${ }^{21}$ Dentro del repertorio de Rigoir no hemos localizado ningún ejemplar idéntico al gijonés, sólo similares.
} 


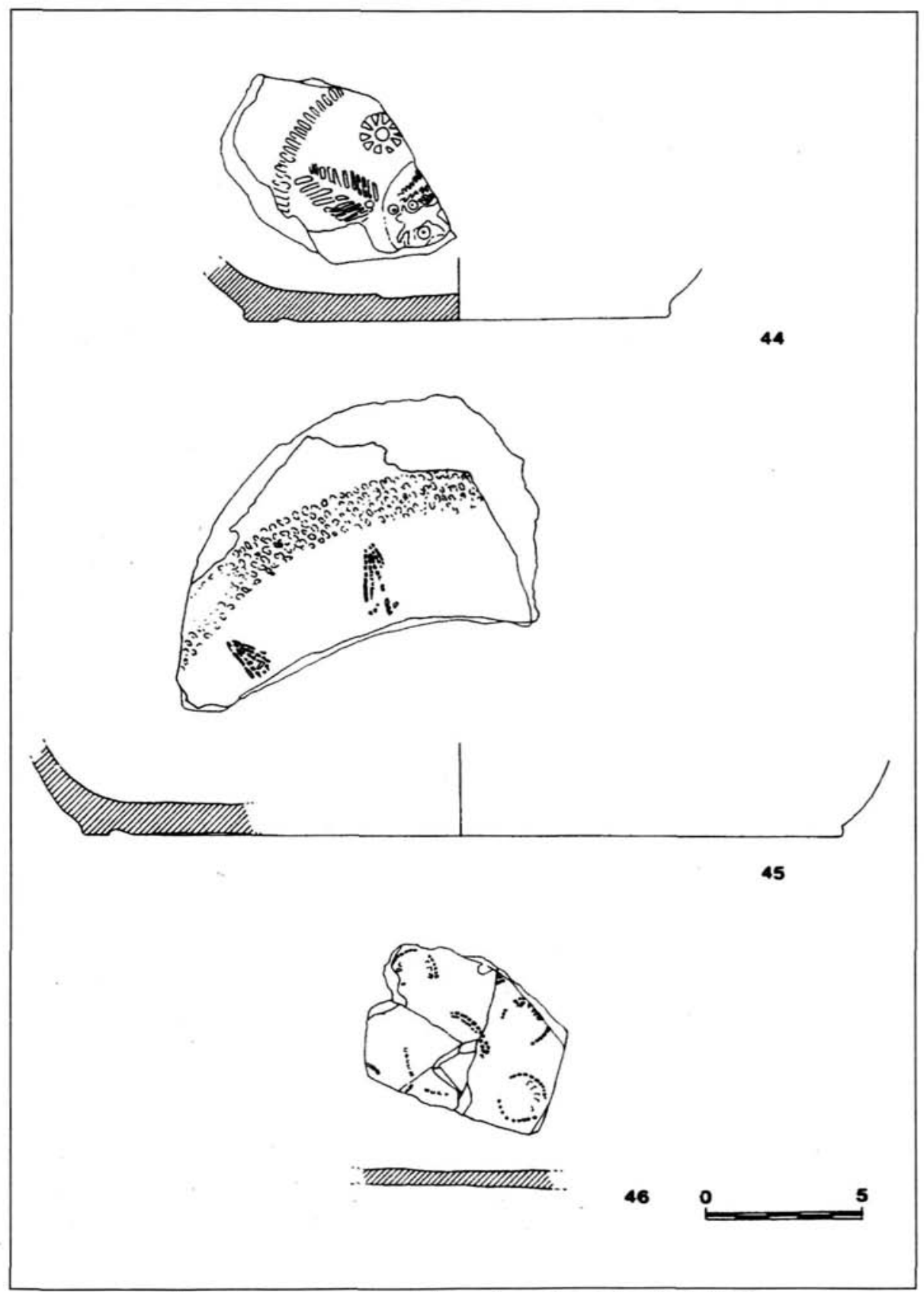

Figura 15. Fragmentos de bases decoradas de t.s.g.t. de Gijón 


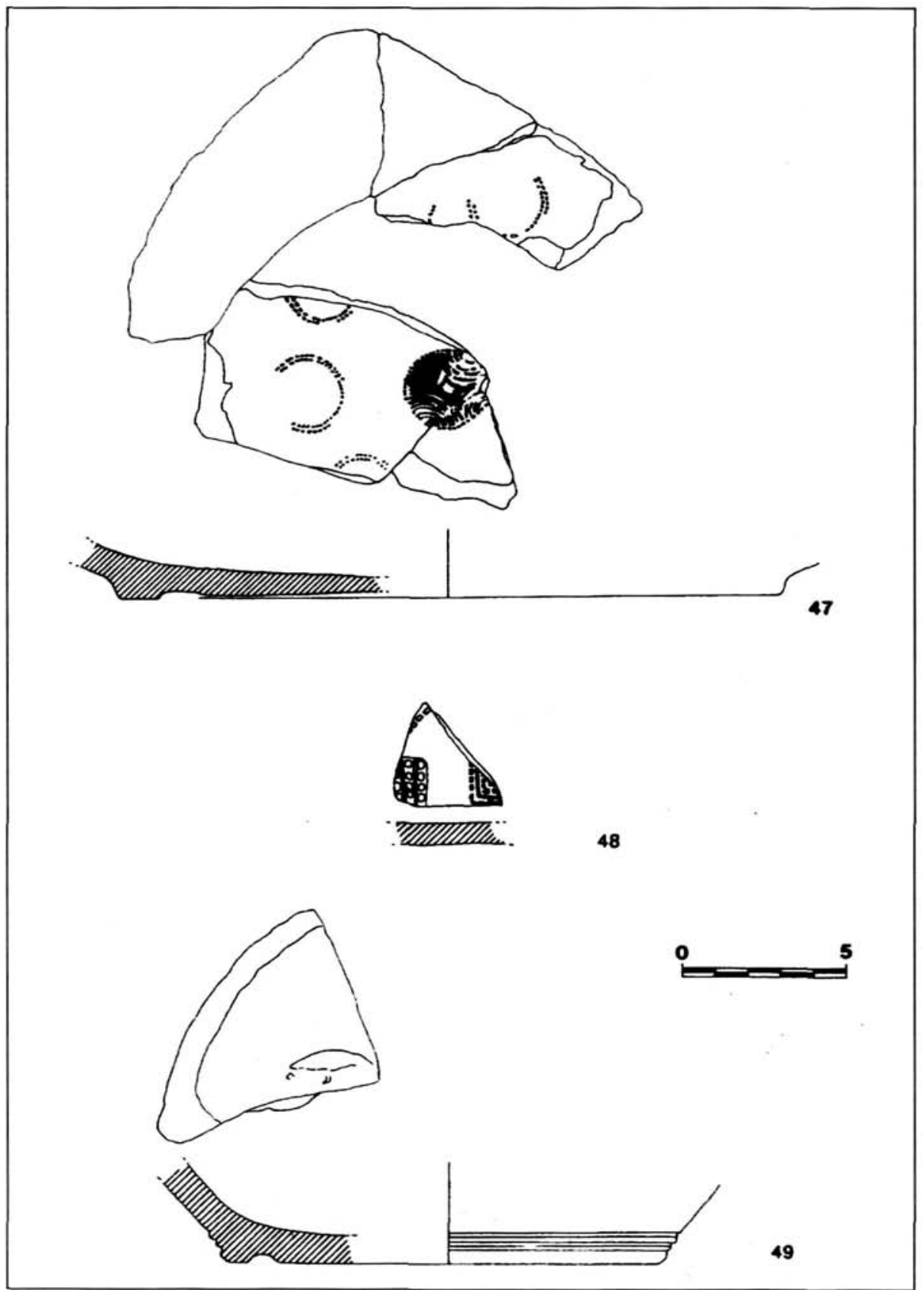

Figura 16. Fragmentos de bases decoradas de t.s.g.t.: 47 y 49) Gijón; 48) Iruaxpe III (VV.AA. 1986:49 sin indicación de escala] 


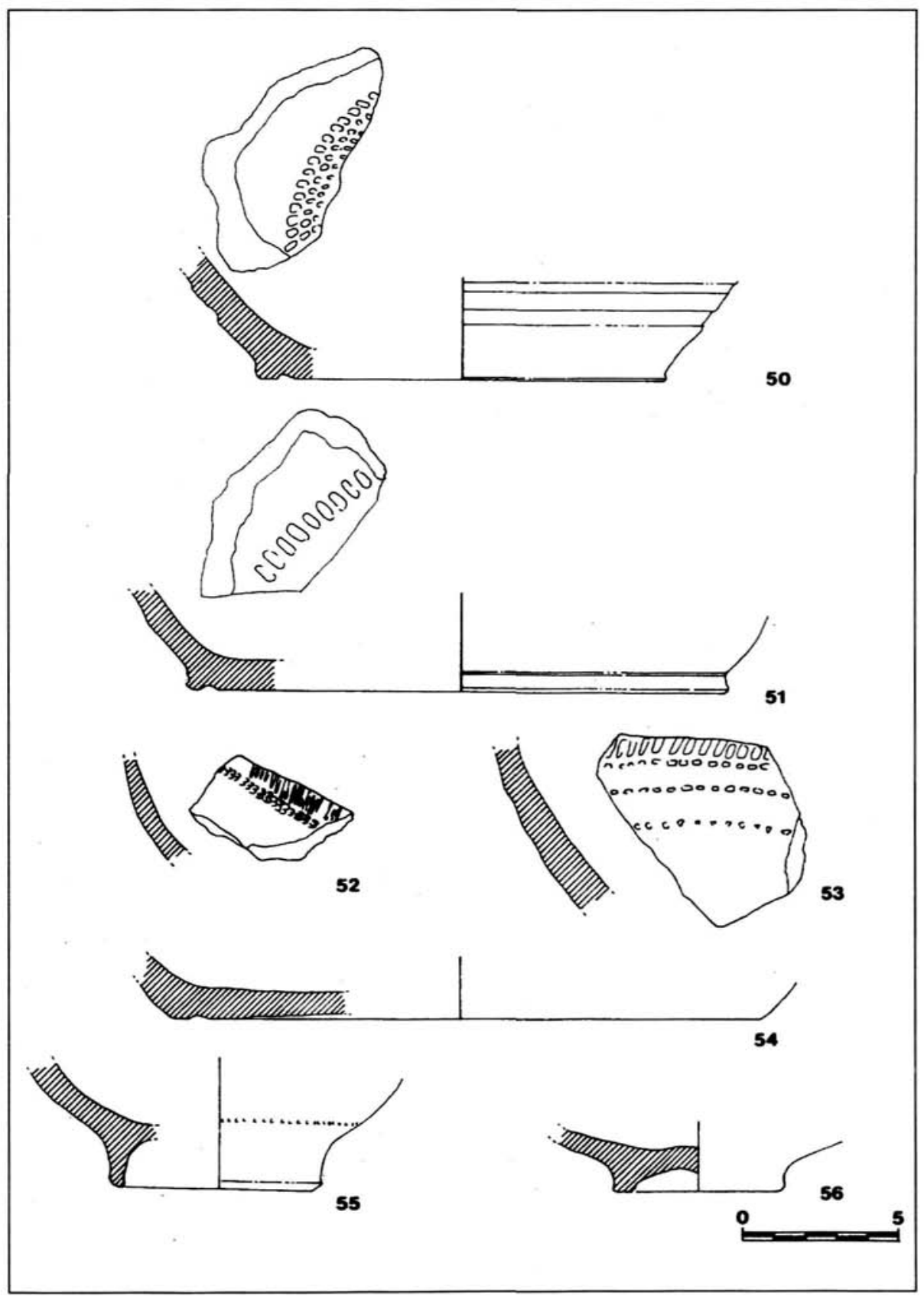

Figura 17. Fragmentos de bases y paredes de t.s.g.t. de Gijón 
central punteado con series de cuartos de círculos concéntricos que forman un rombo en el centro del mismo. Esta estampilla circular es típica del grupo atlántico (Rigoir 1968:196, fig.6). Es similar a un punzón de Poitiers (Rigoir 1968: lám.VII,LXVIII) y a otro publicado por J. e Y. Rigoir y J.F. Meffre (1973: lám.XX,2240).

Dentro de las estampillas geométricas halladas en el norte de Hispania se puede incorporar la de Iruaxpe III de forma cuadrada (fig.16,48) que pudiera adscribirse al taller atlántico (Rigoir y Meffre 1973:254, n. ${ }^{\circ} 2177$ ) aunque, en este caso, es difícil dado el pequeño tamaño del fragmento.

\section{Decoraciones impresas a ruedecilla}

El resto de las piezas de Gijón son bases y paredes decoradas a ruedecilla (fig. 17,50-53) que pueden corresponder tanto a la forma 1 como a la 4 de Rigoir. Incluso hay un ejemplar que muestra restos de una estampilla (fig.16,49) y una base con pie alto que pudieron pertenecer a la forma 16 o 18 de Rigoir (fig.17,55).

\section{IMITACIONES HISPÁNICAS DE T. SIGILLATA GÁLICA TARDÍA}

El fenómeno de las imitaciones es algo muy corriente dentro del mundo tardorromano. En el caso peninsular, las primeras imitaciones identificadas aparecen a finales del siglo IV d.C. en el valle del Duero. El estudio de estas producciones hispánicas se remonta a la década de los años setenta cuando L. Caballero (1972:215) reconoció la existencia de ciertas piezas y decoraciones que, tanto en la versión gris como en la anaranjada, no coinciden con las clásicas publicadas por J. Rigoir; L. Caballero las denominó aimitaciones de cerámica paleocristiana". J. Hayes, por su parte, las llamó eversiones ibéricas de t.s. gris paleocristiana" (Hayes 1980:533).

Las imitaciones hispánicas, a pesar de observarse en algunos casos una influencia norteafricana, deben considerarse filo-gálicas tanto por su cocción reductora como por el tipo de estampillas. Esta filiación fue ya determinada por L. Caballero (1985:118) y se confirma plenamente en el corpus cantábrico.

Estas cerámicas se han localizado en distintas zonas de la Península Ibérica (fig.18): en la villa de Liédana en Navarra (Argente 1979:98), en Lérida (Junyent y Pérez 1985), Villanueva de Azoague en Zamora (López y Regueras 1987:138), Monte Cildá en Palencia (Bohigas y Ruiz 1989:50; Caballero 1972:215), Nájera en La Rioja (Garabito 1983:189), Baños de Valdearados en Burgos (Caballero y Argente 1975: fig.2 y 3), los Tolmos de Caracena en Soria (Jimeno 1979:98; Jimeno, Fernández y Sanz 1980:127), la necrópolis de Taniñe en Soria (Caballero y Argente 1975: fig.4,31-36), Badajoz (Caballero 1972:215), Cancho del Confesionario y Peña Sacra en Madrid (Caballero y Argente 1975: fig.4,31-36), Conímbriga (Delgado 1976:66), Cástulo en Jaén (Molina 1977:1013), fechadas entre los siglos IV y v d.C. 


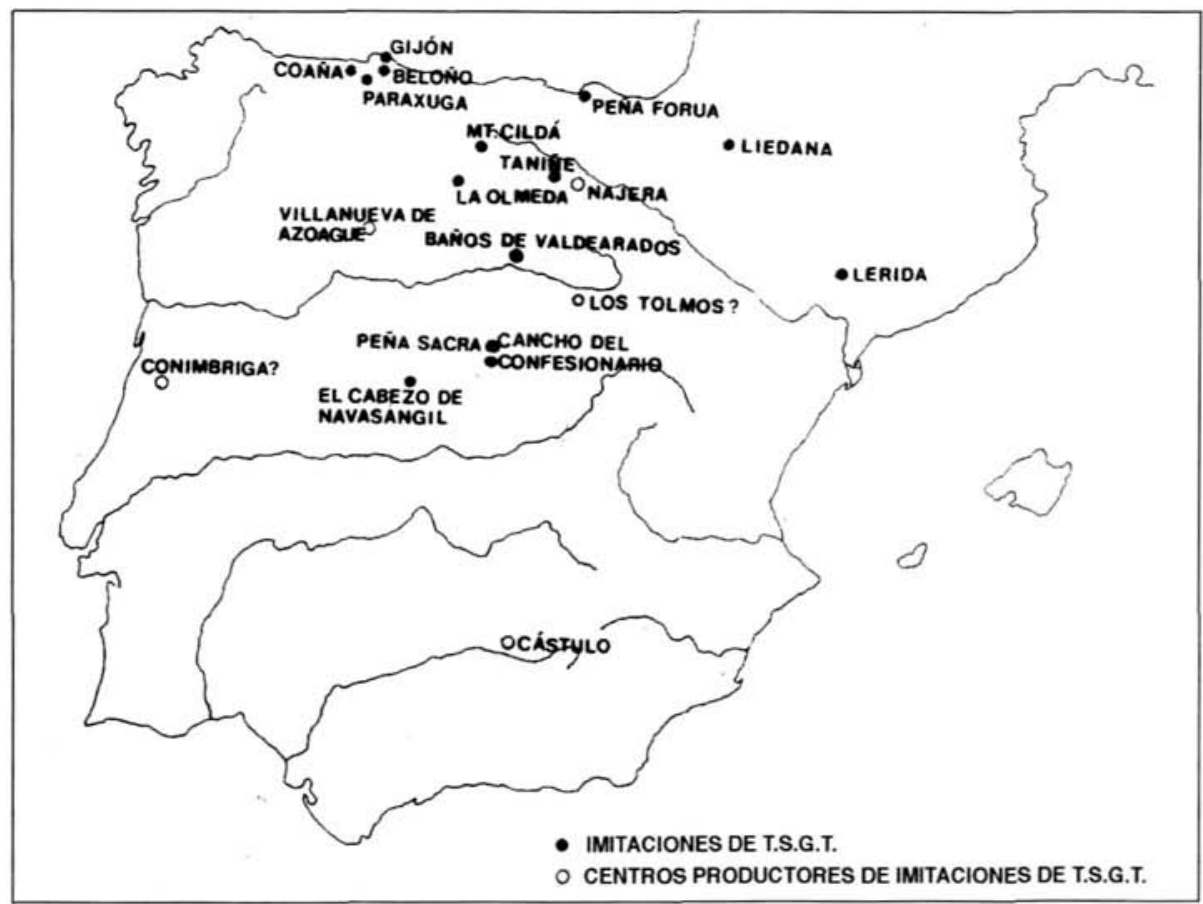

Figura 18. Hallazgos de imitaciones de t.s.g.t. en la Península thérica (1992)

En Asturias y en Peña Forua también se han localizado producciones de este tipo aunque, a diferencia de las zamoranas de Azoague, las formas son, fundamentalmente, cuencos. Se han relacionado con las cerámicas tardorromanas de la Meseta (Carrocera y Requejo 1989:16) y se las ha denominado t.s.h.t. de imitación paleocristiana, siguiendo la terminología de L. Caballero.

\section{Grupo cantábrico de imitaciones de t.s.g.t. ${ }^{22}$}

En los primeros estudios sobre este tema los investigadores ${ }^{23}$ siguieron la clasificación de L. Caballero (1985); según este investigador, durante el desarrollo de las pro-

${ }^{22}$ Esta denominación de grupo cantáhrico tiene un sentido meramente geográfico. Por el momento no estamos en condiciones de adjudicar estas imitaciones a ningún alfar hispano en concreto y, mucho menos, pretendemos dar a entender con esta denominación la existencia de un hipotético alfar cantábrico. Lo que sí es cierto, en lo que concierne a las pastas del grupo gijonés, es que, a simple vista, son distintas de las producciones comunes presumiblemente locales.

${ }^{23} \mathrm{El}$ problema, en el caso asturiano, es que dentro del grupo de imitaciones de t.s.g.t. se han incluido distintos tipos cerámicos (Encinas y García 1992:132; Requejo 1992:140; Carrocera y Requejo 1989:23) ya que se han identificado verdaderas t.s.g.t. del grupo atlántico con imitaciones hispánicas en el caso de las piezas de Paraxuga; esto se debió, fundamentalmente, al estado de conservación de las mismas. No obstante, pudimos comprobar personalmente, en el Museo Arqueológico de Oviedo, que otras piezas de Belono, Coaña y Paraxuga sí pertenecían al grupo de imitaciones hispánicas. 
ducciones de estos talleres hispánicos se observa un paulatino, pero continuo, alejamiento de los modelos gálicos imitados. L. Caballero describe un modelo evolutivo más o menos lineal de las imitaciones hispánicas desde el siglo IV d.C. a las posteriores visigodas del siglo VII d.C. En más de dos siglos las producciones locales o imitaciones se jalonan cronológicamente en dos grupos distintos descritos por este autor:

El grupo Antiguo es el más cercano, morfológica y decorativamente, a los modelos gálicos y coincide, cronológicamente, con la t.s.g.t. (finales del siglo IV y siglo v d.C.). Según L. Caballero (1989:86), se puede considerar aún como sigillata. Este grupo no sólo recibe influencias de los talleres gálicos sino también de los norteafricanos (López y Regueras 1987) o de los hispánicos (Larrén 1989:74). Ejemplos de este grupo antiguo son las iezas de Nájera, Azoague, algún plato de Navasangil (Larrén 1989:56 y 62, fig.1) ${ }^{24}$, los de la villa de la Olmeda ${ }^{25}$ y los de Conímbriga (Delgado 1976:65) que derivan de las formas 1 y 3 de Rigoir (fig.18).

El grupo Avanzado llamado, anteriormente, "imitaciones de las paleocristianas" (Caballero 1985:118). Cronológicamente, son posteriores a las del grupo antiguo (siglos v y vi d.C.) y de peor calidad. Los engobes, cuando existen, no son muy buenos y las piezas se desconchan con facilidad. Las decoraciones estampadas son producto de una evolución local y no una copia de las gálicas. Igualmente, las formas no son idénticas a las galas y, en ocasiones, no se pueden asociar al repertorio de J. Rigoir. Cerámicas de este grupo se han localizado, al parecer, en Cástulo (Molina 1977:1010-1013) y en Cancho del Confesionario (Caballero 1989:86) (fig.18).

Las imitaciones localizadas en Asturias se pueden analizar en tres grandes grupos divididos en razón al tipo de pastas y acabados ${ }^{26}$.

\section{Imitaciones del tipo A}

Las pastas de estas imitaciones son bastante finas, más duras que las de la auténtica t.s.g.t. hallada en Gijón, y tienen un aspecto depurado. Los desgrasantes, de pequeño tamaño, son cuarcíticos y micáceos. La cocción es reductora irregular adquiriendo, las pastas, unas tonalidades grisáceas ${ }^{27}$ (L-51, L-73, M-31 y N-71) y los engobes un tono algo más oscuro (N-70, N-73, P-31 y S-31). En ocasiones se observan zonas de color ocre en la superficie.

${ }^{24}$ Este plato ha sido clasificado por H. Larrén dentro del Grupo Avanzado de L. Caballero.

25 Información oral de D. Javier Cortés.

26 Los tres primeros grupos A, B y C corresponden a los hallazgos de las Termas de Gijón, a los que sumamos otras piezas asturianas que han sido ya estudiadas en una comunicación presentada al I Congreso de Arqueología Peninsular de Oporto (Uscatescu, Fdez Ochoa y García 1993).

27 Las definiciones de los colores se han tomado del código Cailleux, A. Code des couleurs des sols. Ed. Boubée. 
Las formas adoptadas por estas imitaciones tienen cierto aire gálico, pudiendo identificarse con el repertorio de Rigoir. En Gijón destaca la forma Rigoir 4 (fig.19,59). La forma 6a, que procede de Murias de Beloño (Encinas y García 1992:132, fig.1,1 y 34), y la forma $6 \mathrm{~b}$ del castro de Coaña (fig.19,60) (Carrocera y Requejo 1989:23, fig.1,2-3; Escortell 1975:77, lám.LXXXIII).

El resto son fragmentos con decoración estampada, de palmetas en el caso gijonés (fig.19,61) y de motivos fusiformes en Murias de Paraxuga (fig.19,62-63). Es significativa la total ausencia de decoración impresa a ruedecilla, tan típica del grupo atlántico.

Las imitaciones del tipo A no son copias exactas de los modelos gálicos. Este hecho, junto a su determinación cronológica (depósito de mediados del siglo $\mathrm{v}$ a inicios del VI d.C. de las termas de Gijón), hace que se incluyan en un grupo Antiguo/Avanzado de imitaciones, siguiendo la clasificación de L. Caballero. A pesar de que las piezas, sin contexto y, por lo tanto, sin datación segura de Coaña, Paraxuga y Beloño fueron incluidas, anteriormente, dentro del grupo Antiguo (Carrocera y Requejo 1989:27; Requejo 1992:141), clasificación inducida, sin lugar a dudas, por la inclusión de auténtica t.s.g.t. en el grupo asturiano de imitaciones.

\section{Imitaciones del tipo B}

Las pastas y engobes de estas producciones son los más cercanos a los modelos gálicos (fig.20,64-65). Están bien depuradas, aunque son algo más groseras que las de la t.s.g.t. Los acabados se limitan a un espatulado más o menos cuidado y a un engobe aplicado a pincel. La cocción es reductora regular, la pasta es de color gris claro (M-73) y el engobe negruzco o gris oscuro (R-73 o S-73).

Una de las formas recuerda, lejanamente, a la del mortero con listel del grupo atlántico de la forma Rigoir 29 (Rigoir 1968:209, lám.XX), pero la pieza gijonesa (fig.20,65), a diferencia de las gálicas, sí tiene engobe. En Lucentum existen unos morteros asociados a la forma 29 de Rigoir (Reynolds 1987:126) que también llevan un engobe aplicado a pincel, pero aparecen clasificados como t.s.g.t.

Este tipo de imitaciones está representado en Gijón, y fuera de este yacimiento no se conocen ejemplos. Su clasificación como imitaciones no es muy segura y, tan sólo, está avalada por las diferencias existentes entre la auténtica t.s.g.t. y estas piezas.

\section{Imitaciones del tipo C}

Las pastas de estas imitaciones son casi del tipo común pero diferentes de las comunes locales. No llevan engobe. El acabado es un simple alisado más o menos regular y algunas superficies son rugosas. La cocción es reductora irregular, con pastas de color grisáceo y zonas ocres en la superficie. 


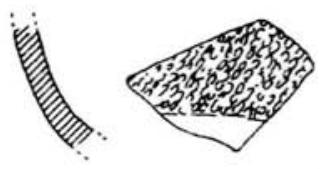

57
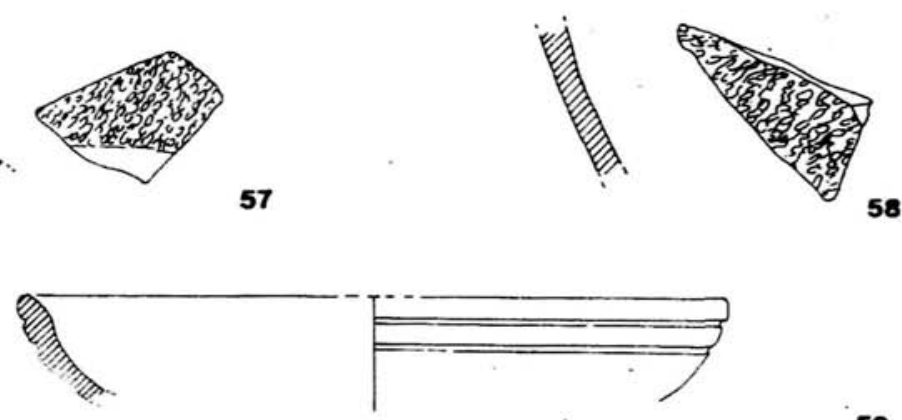

59

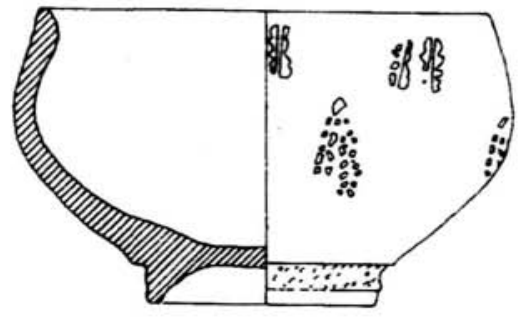

60
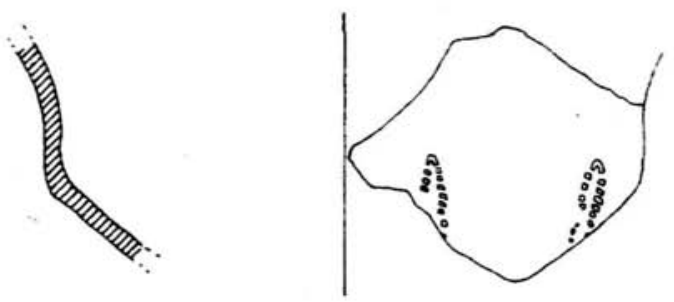

61
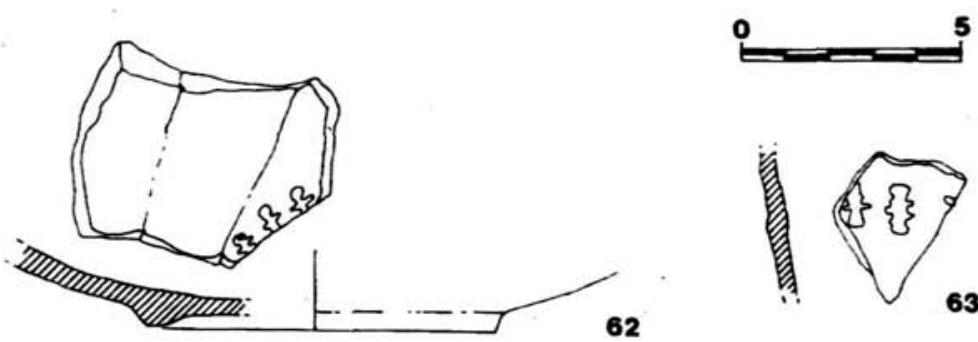

Figura 19. 57-58) fragmentos decorados de t.s.g.t. de Gijón; 59) cuenco de imitación de t.s.g.t. de la forma 4 de Rigoir de Gijón; 60) cuenco de imitación de la forma 6 b de Rigoir del castro de Coaña; 61) fragmento decorado de Gijón; 62-63) fragmentos decorados de Murias de Paraxuga 


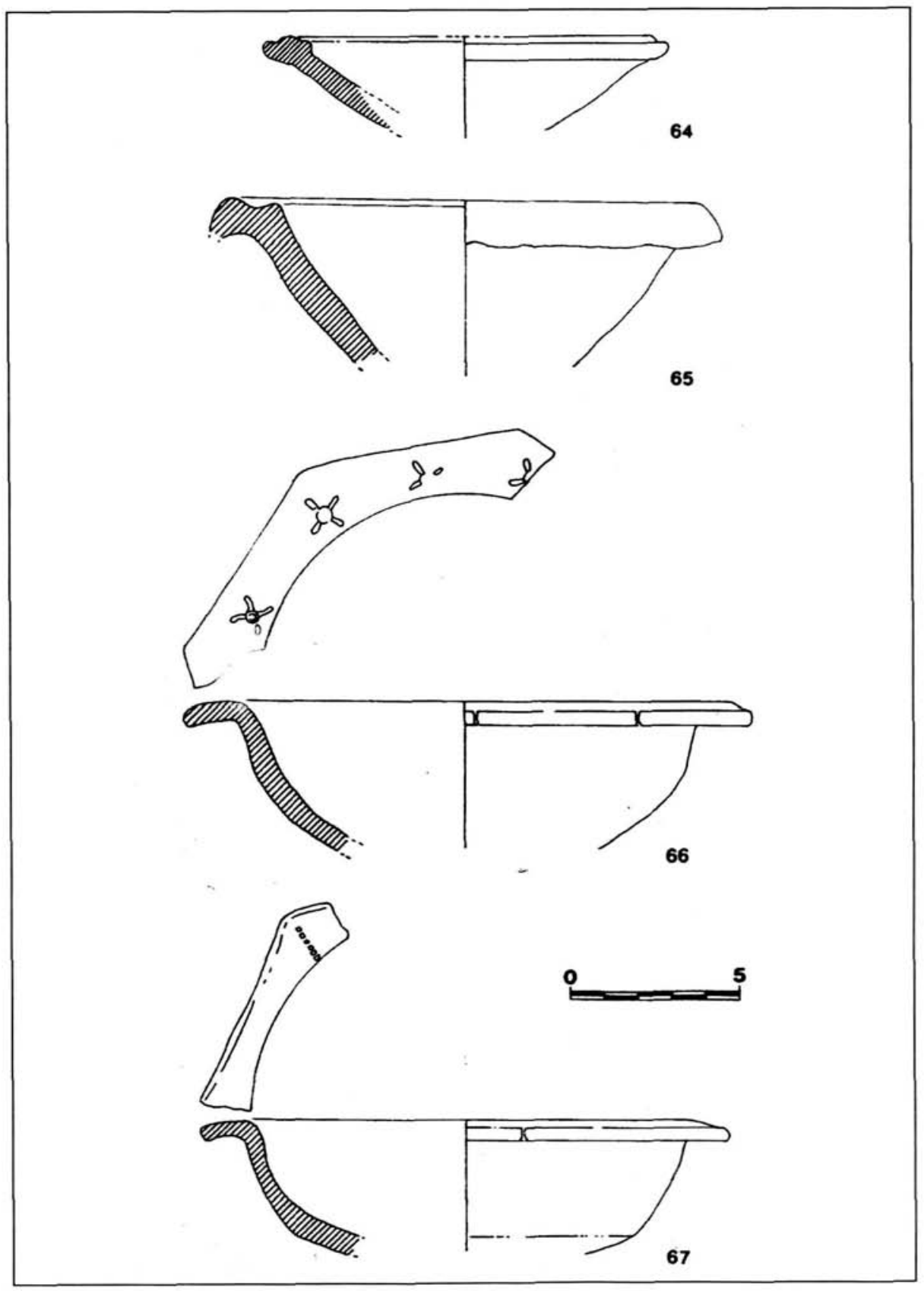

Figura 20. Cuencos de imitación de t.s.g.t. de Gijón; 64-65) imitaciones del tipo B; 66-67) imitaciones del tipo C 


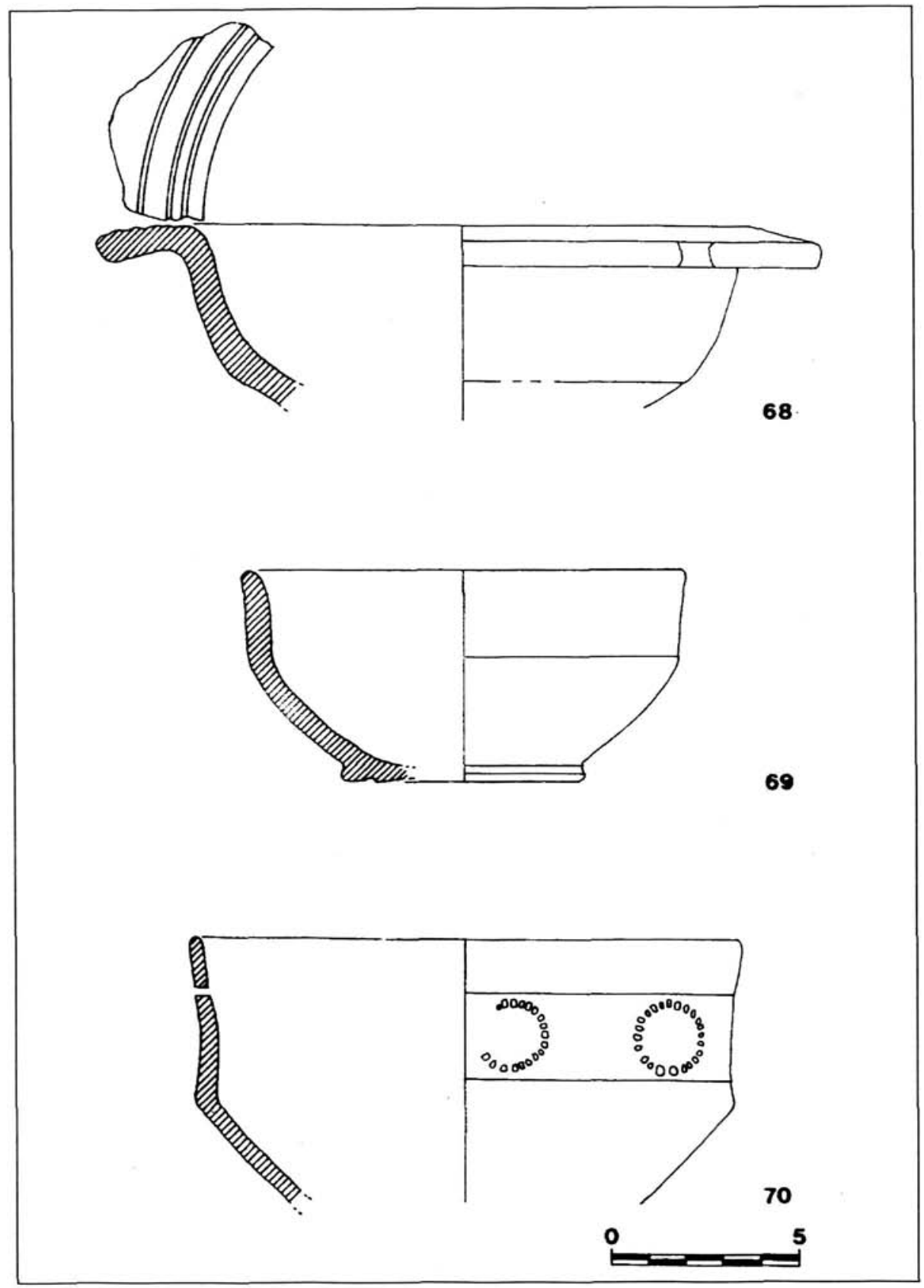

Figura 21. Cuencos de imitación de t.s.g.t.: 68) imitación del tipo C de Gijón; 69-70) imitaciones indeterminadas de Peña Forua [según Martínez y Unzueta 1988: fig.22,71 y fig.21,70] 
La forma es el aspecto más singular de esta imitación. Todas las formas registradas en Gijón corresponden a unos cuencos (fig.20,66-67 y fig.21,68) de borde poligonal, inspirados en la forma Hayes 97 de t.s.a. D (Hayes 1972:151) y, en menor medida, en los cuencos de borde estrellado de la forma 3b de Rigoir (1968:202) que son una versión gálica del modelo norteafricano.

La decoración es siempre estampada con un motivo de aspas con círculo central (fig.20,66) relacionable con otros punzones similares hallados en Monte Cildá (Bohigas y Ruiz 1989:42, fig.5,10-11) y en Nájera (Garabito 1983: fig.4), aunque este modelo de punzón también tiene predecentes en la t.s.h.t. (López Rodríguez 1985: fig.9,18). Por último, otro ejemplar presenta un motivo simple de línea punteada realizado con un punzón de sección cuadrangular (fig.20,67).

Cronológicamente, las imitaciones del tipo C podrían fecharse desde finales del siglo v d.C. a inicios del VI d.C. por las afinidades morfológicas que presentan con respecto al modelo de t.s.a. Hayes 97. Se pueden adscribir al grupo antiguo de imitaciones hispánicas de L. Caballero, aunque sus estampillas, producto de una evolución local o regional, nos induce a pensar que serían de los últimos ejemplares de este grupo.

\section{Imitaciones indeterminadas}

Se incluyen en este apartado dos piezas halladas en Peña Forua que al no haberlas estudiado directamente es difícil determinar su pertenencia a ninguno de los grupos definidos en Asturias. Ambas piezas son cuencos. Uno de ellos podría corresponder a la forma 15 o 16 de Rigoir (fig.21,69) que, aun siendo una producción hispánica, entra dentro de las pautas formales y decorativas de la t.s.g.t. El otro ejemplar (fig.21,70) no pudo paralelizarse con ninguna de las formas de Rigoir y sí con la forma 45 de t.s.h.t.; su decoración de series de círculitos punteados estampados es similar a la de un cuenco estampado gijonés perteneciente a la variedad local de "cerámicas tardorromanas estampilladas e incisas".

\section{VALORACIÓN FINAL}

El repertorio tipológico cantábrico de t.s.g.t. se reduce a las formas 1, 4, 6, 8, 15 , $16,18,20,29$ y 30 de Rigoir de cocción reductora, a las que hay que añadir los fragmentos decorados. Respecto a la cronología de estas importaciones, hay que señalar que, la mayor parte de las piezas registradas en el norte de Espana, no procede de contextos bien fechados; se trata de contextos que arrojan un vasto marco cronológico, mucho más amplio del deseable o lo que es peor, muchas son piezas de excavaciones antiguas. 
La dispersión de la producción atlántica es, fundamentalmente, francesa y se sitúa entre los valles del Loira y del Garona (Rigoir y Meffre 1973:207). Fuera de esta zona sólo se documentaba t.s.g.t. en el yacimiento galés de Dinas Powys. E. Junyent y A. Pérez (1985:913) indicaron que, en el caso peninsular, siempre se había excluido la zona atlántica como proveedora de cerámicas debido a que, salvo el ejemplar de Ampurias ${ }^{28}$, no se había documentado ninguna t.s.g.t. procedente de esa zona gala. El conjunto asturiano y, en especial el lote gijonés ${ }^{29}$, resulta un hallazgo importante ya que, hasta la fecha en Hispania, sólo se conocían las producciones gálicas de los grupos provenzal y languedociano. Esta idea fue inducida por la afirmación de J. e Y. Rigoir (1971:38) quienes indicaron que, hecha la salvedad del ejemplar de Clunia, la producción atlántica no atravesó los Pirineos, que jamás se había documentado su presencia ni en las costas atlánticas españolas ni en las portuguesas. A pesar de esta afirmación, hubo investigadores españoles que intuyeron la pertenencia de algunas piezas de t.s.g.t. al grupo atlántico, caso de L. Caballero (1972:212) con las piezas de Pamplona y Alava ${ }^{30}$ o el de A.M. Benito (1988:158-159) con las del cabo de Higuer. Estos autores plantearon un origen aquitano, bien basado en la similitud morfológica o bien por la posición geográfica de los hallazgos, más cercanos al litoral atlántico francés, considerando además la tradicional relación comercial entre la costa cantábrica peninsular y la atlántica francesa.

En el estado actual de la investigación resulta curioso que Gijón sea el punto más occidental de la presencia de t.s.g.t. del grupo atlántico y que en Galicia, hasta la fecha, no se documente este tipo cerámico; sólo existen referencias sucintas a la presencia de imitaciones de t.s.g.t. (Naveiro 1991:48-49). Así se comprueba cómo la influencia del taller atlántico se restringe a la zona cantábrica y que, incluso en Conímbriga (Delgado 1976:66) no se ha detectado influencia alguna del grupo aquitano, a pesar de existir, entre esta zona y la fachada atlántica francesa, unas relaciones comerciales conocidas desde antiguo.

La presencia en el litoral cantábrico de este tipo de importación se justifica a través de una penetración marítima, fruto de la existencia y mantenimiento de una tráfico regular a lo largo de las costas atlánticas. Esta teoría se hace patente en el caso de las cerámicas del cabo de Higuer, que son producto de desecho de las embarcaciones que recalaban en Asturiaga (Benito 1990:120).

Por otro lado, los puertos del atlántico francés, Nantes o Burdeos, pudieron relacionarse directamente con Hispania (Rigoir 1960:14) pero sólo el estudio directo de las cerámicas en esos yacimientos permitiría establecer con más precisión dicho intercambio

${ }^{28}$ De esta pieza ampuritana hemos recogido, por lo menos, dos referenciass bibligráficas (Junyent y Pérez 1985:913: Paz 1991:208). No aparece recogida en la obra de J. e Y. Rigoir (1971) sobre los ejemplares peninsulares.

29) Todas las piezas halladas en las Termas de Gijón pertenecen a la producción atlántica, excepto dos fragmentos decorados a ruedecilla (fig.19.57-58) cuya adscripción a este grupo es muy dudosa.

${ }^{30}$ Aunque, tras esta revisión, queda patente que ni las piezas de Pamplona ni la de Iruña pertenecen al taller atlántico galo sino, fundamentalmente, al languedociano y, en menor medida, al provenzal. 
comercial. La revisión de excavaciones antiguas, junto con nuevos hallazgos, documentan la existencia de algunos yacimientos de la costa atlántica como Gijón, cabo de Higuer, Burdeos, Dinas Powys o Tintagel, que presentan una clara unidad en las importaciones que circulan por los "finisterres" atlánticos (t.s. africana, t.s. focense y ánforas del Mediterráneo Oriental). Algunos de estos yacimientos debieron ser puertos de escala de una red comercial, en la cual se intercambiaban tanto productos mediterráneos como atlánticos. Esto no resulta extraño pues los intercambios entre las costas atlánticas hispánicas, caso de Oiasso, Gijón y Peña Forua, gálicas y británicas se advierten ya desde época Altoimperial (Redde 1979:481).

En cuanto a la presencia de piezas gálicas de los talleres languedociano y provenzal en la costa cantábrica, caso de Peña Forua, no resulta muy significativa por el momento. Sin embargo, estas producciones se documentan en los yacimientos del interior, Iruña o Pompaelo, relacionados con el valle del Ebro (Paz 1991:209). En este caso no se puede hablar de una vía marítima en la distribución de estas importaciones galas, sino de una penetración por vía terrestre. No se trataría de una re-distribución desde la fachada atlántica de productos languedocianos o provenzales, aunque es sabido que en los yacimientos costeros aquitanos también se localizan importaciones gálicas tardías mediterráneas.

A medida que en la costa cantábrica se desarrollen excavaciones en enclaves de época romana, como queda patente en el caso de Gijón, el volumen de hallazgos de t.s.g.t., seguramente, se verá incrementado siempre que se realice una correcta identificación de las producciones. De este modo podremos llegar a conocer el alcance real que tuvo el taller aquitano fuera del habitual y conocido marco de distribución francés.

\section{INVENTARIO DE LAS ILUSTRACIONES ${ }^{31}$}

1. Fragmentos de borde, pared y base de t.s.g.t. Pasta muy depurada de textura talcosa. Color gris, en fractura (N-73) y en superficie (M-73). Desgrasantes muy finos en superficie. Engobe totalmente perdido. Decoración de ruedecilla en el borde y en el interior alrededor de series de estampillas de palmetas en disposición radial. Diám. del borde $=336 \mathrm{~mm}$. Altura $=44 \mathrm{~mm}$. Forma Rigoir 1. Gijón $\left(\right.$ sector E/Z-8/N.VI/N. ${ }^{\circ}$ inv. 6855 y 6860 ). Figura 4,1 .

2. Fragmentos de borde, pared y base de t.s.g.t. Pasta gris muy clara (M-73) muy depurada. Escasos restos del engobe gris muy oscuro (T-73) en el exterior. Decoración: incisiones perpendiculares en el borde y ruedecilla en el interior. Diám. del borde $=$

${ }^{31}$ En este inventario sólo incluimos la descripción de las piezas que hemos dibujado y estudiado directamente, es decir, las cerámicas procedentes de las excavaciones de Gijón y las que se exhiben en el Museo Arqueológico de Oviedo, de Murias de Paraxuga y de Coaña. 
$298 \mathrm{~mm}$. Altura $=32 \mathrm{~mm}$. Forma Rigoir 1. Gijón (sector E/Z-8/N.V/N. ${ }^{\circ}$ inv. 6830/N.VI/ N. ${ }^{\circ}$ inv. 6860). Figura 4,2 .

3. Fragmento de borde de t.s.g.t. Pasta gris clara (M-73). Engobe totalmente perdido. Restos de decoración incisa en el borde: trazos perpendiculares. Diám. del borde $=324 \mathrm{~mm}$. Forma Rigoir 1. Murias de Paraxuga. Figura 5,3.

4. Fragmento de borde, pared y base de t.s.g.t. Pasta gris (N-73) muy depurada. Desgrasantes finos de cuarzo. Engobe de tacto jabonoso de color gris oscuro (T-73). Diám. del borde $=220 \mathrm{~mm}$. Forma Rigoir 4. Gijón (sector E/Z-4/N.V/N. ${ }^{\circ}$ inv. 7803). Figura 7,10 .

5. Fragmentos de borde, pared y base de t.s.g.t. Pasta gris (L-73) muy depurada. Restos de engobe negruzco (T-73) de tacto jabonoso en el interior y en el exterior. Presenta dos acanaladuras en el exterior de la pieza. Diám. del borde $=250 \mathrm{~mm}$. Diám. de la base $=205 \mathrm{~mm}$. Altura $=38 \mathrm{~mm}$. Forma Rigoir 4. Gijón (sector $\mathrm{E} / \mathrm{Z}-8 / \mathrm{N} . \mathrm{VI} / \mathrm{N}{ }^{\circ}{ }^{\circ}$ inv. 6860/perfiles/N. ${ }^{\circ}$ inv. 9609). Figura 7,11.

6. Fragmento de borde y pared de t.s.g.t. Pasta gris (M-73) muy depurada. Desgrasantes finos de cuarzo. Restos de engobe negruzco (T-73) de tacto jabonoso en el interior y en las acanaladuras exteriores. Diám. del borde $=272 \mathrm{~mm}$. Forma Rigoir 4 . Gijón (sector E/Z-4/N.VII/N. ${ }^{\circ}$ inv. 5738). Figura 7,12.

7. Fragmento de borde, pared y comienzo de base de t.s.g.t. Pasta gris clara (M73) muy depurada de textura talcosa. Engobe de tacto jabonoso de color gris oscuro (S73), conservado en las acanaladuras exteriores. Decoración impresa a ruedecilla en el fondo. Diám. del borde $=318 \mathrm{~mm}$. Forma Rigoir 4. Murias de Paraxuga. Figura 7,13.

8. Fragmento de borde de t.s.g.t. Pasta muy depurada de color gris claro (N-71). Desgrasantes muy finos micáceos. Engobe totalmente perdido. Diám. del borde $=160$ mm. Forma Rigoir 16. Gijón (sector E/Z-4/N.VIII/N. ${ }^{\circ}$ inv. 7840). Figura 11,29.

9. Fragmento de borde de t.s.g.t. Pasta muy depurada de color gris claro (N-71). Desgrasantes finos de cuarzo. Engobe de color gris oscuro (T-73), mal conservado, interior de tacto jabonoso y exterior espatulado. Diám. del borde $=172 \mathrm{~mm}$. Forma Rigoir 16. Gijón (sector E/Z-4/N.VI/N. ${ }^{\circ}$ inv. 6248). Figura 11,30.

10. Fragmento de borde de $t$.s.g.t. Pasta muy depurada de color gris claro (M-73). Desgrasantes finos de cuarzo. Engobe de tacto jabonoso de color gris oscuro (T-73), conservado en el interior y en las acanaladuras del exterior. Diám. del borde $=237 \mathrm{~mm}$. Forma Rigoir 16. Gijón (sector E/Z-4/N.II/N. ${ }^{\circ}$ inv. 6322). Figura 11,31.

11. Fragmento de borde de t.s.g.t. Pasta muy depurada de color gris claro (M-73). Desgrasantes muy finos de cuarzo. Engobe de color gris oscuro (T-73) muy mal conservado. Diám. del borde $=136 \mathrm{~mm}$. Forma Rigoir 18. Gijón $\left(\right.$ sector E/Z-4/N.VIII/N. ${ }^{\circ}$ inv. 7850). Figura 12,34. 
12. Fragmento de borde y pared de t.s.g.t. Pasta muy depurada de color gris claro (M-73). Engobe de tacto jabonoso de color gris claro (N-31). Dos acanaladuras en el exterior. Diám. del borde $=200 \mathrm{~mm}$. Forma Rigoir 30. Gijón (sector E/Z-8/N.V/N. ${ }^{\circ}$ inv. 6830). Figura 12,39.

13. Fragmento de base de t.s.g.t. Pasta muy depurada de color gris (M-73). Desgrasantes finos de cuarzo. Engobe gris oscuro (T-73) de tacto jabonoso. Diám. de la base $=135 \mathrm{~mm}$. Decoración impresa a ruedecilla y estampada: ciervo, palmeta y roseta. Forma indeterminada. Gijón (sector E/Z-4/N.III/N. ${ }^{\circ}$ inv. 6574). Figura 15,44.

14. Fragmento de base de t.s.g.t. Pasta muy depurada de color gris (N-71). Restos de engobe de color negruzco (T-73) de tacto jabonoso. Decoración impresa a ruedecilla y estampada: palmetas dispuestas de forma radial. Forma indeterminada. Gijón (sector E/Testigo Z-4 y Z-6/N. ${ }^{\circ}$ inv. 8283 bis). Figura 15,45.

15. Fragmentos de base de t.s.g.t. Pasta muy depurada de color gris (M-73). No conserva el engobe. Pieza muy rodada de textura talcosa. Decoración estampada: series de círculos punteados y círculos radiados. Forma indeterminada. Gijón (sector E/Z-8/ N.VI/N. ${ }^{\circ}$ inv. 6860). Figura 15,46.

16. Fragmentos de base de t.s.g.t. Pasta muy depurada de color gris claro (L-73). Restos de engobe gris oscuro (N-73). Diám. de la base $=196 \mathrm{~mm}$. Decoración estampada: círculo central punteado con arquitos concéntricos en su interior y a su alrededor series de círculos punteados. Forma indeterminada. Gijón (sector E/Testigo Z-4 y Z-6/N. ${ }^{\circ}$ inv. 8283 bis). Figura 16,47 .

17. Fragmento de base de t.s.g.t. Pasta muy depurada de color gris (M-73). Engobe de tacto jabonoso de color gris oscuro (T-73). Restos de decoración estampada. Diám. de la base $=130 \mathrm{~mm}$. Forma indeterminada. Gijón (sector E/Z-4/N.VII/N. ${ }^{\circ}$ inv. 7840). Figura 16,49.

18. Fragmento de base de t.s.g.t. Pasta muy depurada de color gris (L-73). Engobe gris oscuro (N-71) de tacto jabonoso. Restos de decoración impresa a ruedecilla en el interior de la pieza. Diám. de la base $=130 \mathrm{~mm}$. Forma indeterminada. Gijón (sector E/ Z-7/N.III/N. ${ }^{\circ}$ inv. 6537). Figura 17,50.

19. Fragmento de base de t.s.g.t. Pasta muy depurada de color gris (L-73). Restos de engobe en ambas superficies de color gris oscuro (T-73). Restos de una decoración impresa a ruedecilla en el interior. Diám. de la base $=170 \mathrm{~mm}$. Forma indeterminada. Gijón (sector E/Z-4/N.VIII/N. ${ }^{\circ}$ inv. 7860). Figura 17,51.

20. Fragmento de pared de t.s.g.t. Pasta muy depurada de color gris (M-73). Desgrasantes muy finos de cuarzo. No conserva el engobe. Restos de decoración en el interior. Forma indeterminada. Gijón (sector E/Z-4/N.VIII/N. ${ }^{\circ}$ inv. 7849). Figura 17,52.

21. Fragmento de pared de t.s.g.t. Pasta depurada de color gris (N-71). Desgrasantes finos cuarcíticos. Conserva el engobe de color gris oscuro (T-73) en el exterior de 
la pieza. Restos de decoración a ruedecilla en el interior. Forma indeterminada. Gijón (sector E/Z-4/N.VIII/N. ${ }^{\circ}$ inv. 7860). Figura 17,53.

22. Fragmento de base de t.s.g.t. Pasta muy depurada de color gris claro (M-73). Restos de engobe negruzco (T-73) en la acanaladura del repie. El resto de la pieza ha perdido el engobe. Diám. de la base $=190 \mathrm{~mm}$. Forma indeterminada. Gijón (sector E/ Z-8/N.V/N. ${ }^{\circ}$ inv. 6830 y 6845 ). Figura 17,54 .

23. Fragmento de base anular de t.s.g.t. Pasta muy depurada de color gris (M-73). Desgrasantes muy finos. No conserva el engobe. Diám. de la base $=65 \mathrm{~mm}$. Restos de decoración en el exterior. Forma indeterminada. Gijón (sector E/Z-4/N.IX/N. ${ }^{\circ}$ inv. 7894). Figura 17,55.

24. Fragmento de base anular de t.s.g.t. Pasta muy depurada de color gris claro (M-73). Restos de engobe de tacto jabonoso de color gris oscuro (P-73) conservado en el exterior. Diám. de la base $=54 \mathrm{~mm}$. Forma indeterminada. Gijón (sector E/Testigo Z4 y Z-6/N. ${ }^{\circ}$ inv. 8283 bis). Figura 17,56.

25. Fragmento de pared de t.s.g.t. Pasta dura, muy depurada de color gris claro (M-73). Engobe de color negruzco (S-73). Decoración burilada en el exterior. Forma indeterminada. Gijón (sector E/Z-5/Hypocaustum/N. ${ }^{\circ}$ inv. 8561). Figura 19,57.

26. Fragmento de pared de $t . s . g . t$. Pasta dura, muy depurada de color gris oscuro (N-31). Engobe de color negruzco (T-31) muy bien conservado. Decoración burilada en el exterior. Forma indeterminada. Gijón (sector E/Testigo Z-4 y Z-6/N. ${ }^{\circ}$ inv. 8283 bis). Figura 19,58.

27. Fragmento de borde de imitación de t.s.g.t. del tipo A. Pasta gris clara (L-73). Restos de engobe gris oscuro (N-73). Dos acanaladuras en el exterior. Diám. del borde indeterminado. Prototipo: forma Rigoir 4. Gijón (sector E/Z-8/N.VI/N. ${ }^{\circ}$ inv. 6860). Figura 19,59 .

28. Cuenco casi completo de imitación de t.s.g.t. del tipo A. Pasta gris clara (N71). Desgrasantes muy finos. Engobe irregular de color gris oscuro y ocre (N-70 y R-73). Espatulado en el exterior. Cocción reductora muy irregular. Decoración estampada: series de palmetas y de motivos fusiformes. Diám. del borde $=102 \mathrm{~mm}$. Diám. de la base $=50 \mathrm{~mm}$. Altura $=66 \mathrm{~mm}$. Prototipo: forma Rigoir 6b. Castro de Coaña. Figura 19,60.

29. Fragmento de pared, con carena suave, de cuenco. Imitación de t.s.g.t. del tipo A. Pasta muy fina gris clara (L-31). Engobe negruzco (S-31) mal conservado, de tacto suave. El engobe es bastante cohesivo con la pasta donde se conserva. Decoración estampada en el exterior: dos palmetas. Gijón (sector E/Z-8/N.VI/N. ${ }^{\circ}$ inv. 6860). Figura 19,61.

30. Fragmentos de base anular de imitación de t.s.g.t. del tipo A. Pasta gris (M31). Engobe de color gris oscuro (P-31). Alisado exterior. Decoración estampada: series 
de motivos fusiformes dispuestos en círculo. Diám. de la base $=78 \mathrm{~mm}$. Forma indeterminada. Murias de Paraxuga. Figura 19,62.

31. Fragmento de base de imitación de t.s.g.t. del tipo A (probablemente sea de la misma pieza $\mathrm{n}^{\circ}$ 30). Pasta gris (M-31). Engobe fino y cohesivo de color gris oscuro (P-31). Espatulado exterior. Decoración estampada: series de motivos fusiformes. Forma indeterminada. Murias de Paraxuga. Figura 19,63.

32. Fragmento de base moldurado y pared de cuenco. Imitación de t.s.g.t. del tipo B. Pasta depurada gris clara (M-73). Engobe gris muy oscuro (R-73) conservado en el interior y aplicado a pincel. Diám. del borde indeterminado. Gijón (sector E/Z-8/N.VIII (perfiles)/N..$^{\circ}$ inv. 9575). Figura 20,64.

33. Fragmento de borde exvasado y pared de cuenco. Imitación de t.s.g.t. del tipo B. Pasta depurada gris clara (M-73). Engobe negruzco (S-73) aplicado a pincel. Huellas de espatulado en el interior y en el exterior. Diám. interior del borde $=116 \mathrm{~mm}$. Prototipo: forma Rigoir 29. Gijón (sector E/Z-8/N.VI/N. ${ }^{\circ}$ inv. 6860). Figura 20,65.

34. Fragmento de borde poligonal y pared de cuenco. Imitación de t.s.g.t. del tipo C. Pasta depurada de color gris pardusco y ocre en zonas. Cocción reductora irregular. Desgrasantes finos y medios de cuarzo. Superficie áspera. Decoración estampada en el borde: series de aspas cruzadas con círculo central. Forma: prototipo Hayes 97. Diám. interior del borde $=144 \mathrm{~mm}$. Gijón (sector E/Z-4/N.IX/N. ${ }^{\circ}$ inv. 7894). Figura 20,66.

35. Fragmento de borde poligonal y pared de cuenco. Imitación de t.s.g.t. del tipo C. Pasta depurada grisácea con desgrasantes micáceos. Cocción reductora no muy homogénea. Decoración impresa en el borde: línea punteada. Forma: prototipo Hayes 97. Diám. interior del borde $=128 \mathrm{~mm}$. Gijón (sector E/Z-4/N.IX/N. ${ }^{\circ}$ inv. 7880). Figura 20,67.

36. Fragmento de borde y pared de cuenco de borde poligonal. Imitación de t.s.g.t. del tipo C. Pasta depurada de color gris pardusco y ocre en zonas. Desgrasantes medios de cuarzo. Cocción reductora irregular. Superficie rugosa. Borde moldurado o con acanaladuras. Forma: prototipo Hayes 97. Diám. interior del borde $=140 \mathrm{~mm}$. Gijón (sector E/Z-4/N.IX/N. ${ }^{\circ}$ inv. 7894). Figura 21,68.

\section{BIBLIOGRAFÍA}

Alvargonzález, C., 1965: Las Termas romanas de Gijón. Ayuntamiento de Gijón.

APELLÁNIZ, J. M., 1973: “Corpus de materiales de las culturas prehistóricas con cerámica de la población de las cavernas del País Vasco Meridional. Munibe, supl. 1. San Sebastián.

- 1974: "El grupo de los Husos durante la prehistoria con cerámica en el País Vasco". $E A A, 7$. Vitoria. 
ARGENTE, J. L., 1979: "La villa tardorromana de Baños de Valdearados (Burgos)". EAE, 100. Madrid.

BELTRÁN, M., 1978: Cerámica romana. Tipología y clasificación. Zaragoza.

BENITO, A. M., 1988: “Cerámicas del yacimiento submarino del cabo de Higuer (Hondarribia)". Munibe, 40. San Sebastián, pp. 123-163.

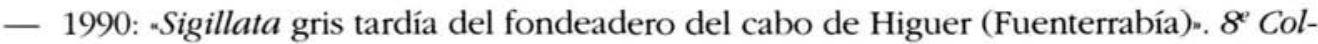
loqui Internacional d'Arqueologia de Puigcerdà (1988): La Romanització del Pirineu. Puigcerdà, pp. 119-130.

BOHíGAS, R., y RuIZ, A., 1989: “Las cerámicas visigodas de poblado en Cantabria y Palencia-. BolArqMed,3. Madrid, pp.31-51.

Bourgeois, A., y MAYET, F., 1991: Fouilles de Belo. Belo IV: les sigillées. Collection de la Casa de Velazquez. Archéologie XIV. Madrid.

CABAllero, L., 1966: „Un vaso tardorromano de Iruña (Alava)». AEspArq, 39. Madrid, pp.138-139.

- 1972: "Cerámica sigillata gris y anaranjada paleocristiana en España". Separata de TP, 29. Madrid.

- 1974: "Cerámica sigillata clara del tipo D estampada de las provincias de Murcia y Almería". Miscelánea Arqueológica. Madrid, pp.193-222.

- 1985: "Hallazgo de un conjunto tardorromano en la calle sur de Getafe (Madrid)». Boletín del Museo Arqueológico Nacional, III (1). Madrid, pp.92-127.

- 1989: "Cerámicas de época visigoda y post-visigoda de las provincias de Cáceres, Madrid y Segovia-. BolArqMed,3. Madrid, pp. 75-107.

CABAllero, L., y ARGente, J. L., 1975: “Cerámica paleocristiana gris y anaranjada producida en España. TP, 32. Madrid, pp.113-146.

CARROCERA, E., y REQUEJO, O., 1989: „Producciones cerámicas tardías en castros y villas asturianas". BolArqMed, 3. Madrid, pp.21-30.

CAZUrRo, M., 1909-10: "Terra Sigillata. Los vasos aretinos y sus imitaciones galo-romanas en Ampurias". Anuari del Institut d'Estudis Catalans, III. Barcelona, pp. 296-360.

CERRILlo, E., y J., 1984-85: -Acerca del origen de la producción local de cerámicas estampilladas del siglo IV-V*. Zephyrus, 37-38. Salamanca, pp.361-369.

Courtieu, J. et al., 1980: "Dérivées des sigillées paléochrétiennes de l'Aude. Un atelier carcassonais?". Bulletin de la Societé d'Études Scientifiques de l'Aude, 80. Carcasona, pp.35-68. 
DAURA, A., y PARDO, D., 1990: "Nous testimonis de la Baixa Romanitat a les conques mitjana i alta del Cardener i el Llobregat". $8^{\grave{e}}$ Col-loquí Internacional d'Arqueologia de Puigcerdà (1988): La Romanització del Pirineu. Puigcerdà, pp. 143-151.

DeChelette, J., 1904: Les vases céramiques ornées de la Gaule romaine. París.

Delgado, M., 1976: “Céramiques grises du Bas-Empire». Fouilles de Conimbriga VI: céramiques diverses et verres. París, pp.65-69.

EnCINAS, M., y GARCÍA, A., 1992: "Aportaciones al conocimiento de la transición del mundo romano medieval en Asturias: las cerámicas de Murias de Beloño y de Paraxuga". III CAME. Oviedo, pp. 131-139.

ESCORTElL, M., 1975: Catálogo de las salas de cultura romana del Museo Arqueológico de Oviedo. Oviedo.

Esteban, M., 1990: El País Vasco atlántico en época romana. Mundaiz, 6. San Sebastián.

FERNÁNDEZ OCHOA, C., 1982: Asturias en la época romana. Universidad Autónoma de Madrid.

FERNÁNDEZ OCHOA, C.; GaRCÍA, P., y USCATESCU, A., 1992: “Gijón en el período Tardoantiguo: las cerámicas importadas de las excavaciones de Cimadevillan. AEspArq, 65. Madrid, pp.105-149.

- 1993: "Addendum a Gijón en el período Tardoantiguo: las cerámicas importadas de las excavaciones de Cimadevilla, AEspArq, 65". AEsArq, 66. Madrid, pp.329-330.

GARABITO, T., 1983: "El centro de producción de sigillata hispánica tardía en Nájera". Cuadernos de Investigación. I Coloquio sobre Historia de La Rioja (1982). Tomo IX, fasc. 1. Logroño, pp.187-197.

GAUTHIER, M., 1975: "La céramique estampée tardive d'Aquitaine". Revue bistorique de Bordeaux et du département de la Gironde, XXIV. Burdeos, pp.19-45.

GIL, E.; FILlOY, I., e IRIARTE, A., 1991: "Estructuras urbanas en el yacimiento romano de Iruña (Trespuentes, Alava). Estado de la cuestión". La Casa Urbana Hispanorromana. Zaragoza, pp.281-286.

HAYES, J. W., 1972: Late Roman Pottery. A Catalogue of Roman Fine Wares. The British School at Rome. Londres.

- 1976: "Pottery: Stratified Groups and Typology". HUMPHREY, J.H. (ed.) Excavations at Carthage Conducted by the University of Michigan, 1975. Vol. I. Ann Arbor, pp.47-123.

- 1977: "North African Flanged Bowls: a Problem in the Fifth Century Chronology". DORE, J. y GREENE, K. (eds.) Roman Pottery Studies and Beyond. Papers Presented to J. Gilman. BAR inter. Ser., 30. Oxford, pp.279-287.

- 1980: Supplement to Late Roman Pottery. The British School at Rome. Londres. 
JIMENO, A., 1979: •Aportación al estudio de las necrópolis del Duero: Los Tolmos, Caracena (Soria). Revista de Investigación, III (1). Soria, pp.91-105.

Jimeno, A.; FERNANDEZ, J. J., y SANZ, A., 1980: "La cerámica sigillata decorada y de imitación de los Tolmos, Caracena (Soria).. Revista de Investigación, IV. Soria, pp.121-132.

JUNYENT, E., y PÉREZ, A., 1985: "Las cerámicas paleocristianas de la Paeria, Lleida". XVII CNA (Logroño 1983). Zaragoza, pp.903-914.

LARREN, H., 1989: "Materiales cerámicos de La Cabeza: Navasangil (Avila)». BolArqMed,3. Madrid, pp.53-74.

LÓPEZ RODRíguez, J. R., 1985: Terra sigillata hispánica tardía decorada a molde de la Península Ibérica. Salamanca.

LÓPEZ, J. R., y REgueras, F., 1987: “Cerámicas tardorromanas de Villanueva de Azoague (Zamora).. BSAA, 53. Valladolid, pp.115-166.

MAÑANES, T., 1980: "La cerámica tardorromana-visigoda anaranjada y gris con decoración estampada en la España Nor-occidental. Studia Archaeologica, 65. Valladolid, pp.215-250.

Martínez, A., y Unzueta, M., 1988: Estudio del material romano de la cueva de Peña Forua (Forua-Vizcaya). Cuadernos de Arqueología de Deusto, 11. Bilbao.

MASSAL, E.; RIGOIR, Y., y RIGOIR, J., 1979: "Les DPS à Cessero-Saint-Thibéry (Hérault)". Documents d'Archéologie Meridionale, 2. Lambesc, pp. 158-184.

MAYET, F., 1984: Les céramiques sigillées Hispaniques. Contribution à l'bistoire économique de la Péninsule Ibérique sous l'Empire romain. París.

Mezquíriz, M. A., 1978: Pompaelo II. Príncipe de Viana. Excavaciones en Navarra, 9. Pamplona.

MolinA, F., 1977: "La sigillata paleocristiana autóctona y sus relaciones con la cerámica pintadam. XIV CNA (Vitoria 1975). Zaragoza, pp.999-1014.

NAVEIRO, J., 1991: El comercio antiguo en el NW peninsular. Monografías Urxentes do Museu, 5. La Coruña.

Nieto Gallo, G., 1958: El Oppidum de Iruña. Vitoria.

PALOL, P. de, 1948: "La cerámica estampada romano cristiana". IV Congreso Arqueológico del Sudeste Español. Elche, pp.450-469.

PAZ, J. A., 1991: Cerámica de mesa romana de los siglos III al VI d.C. en la provincia de Zaragoza. Institución Fernando el Católico. Zaragoza.

REDDE, M., 1979: :La navigation au large des côtes atlantiques de la Gaule à l'époque romaine". MEFRA, 91. Roma, pp.481-489. 
ReQuejo, O., 1992: "Cerámicas tardorromanas de la villa de Murias de Paraxuga". III CAME. Oviedo, pp.131-139.

REYNOLDS, P., 1987: El yacimiento tardorromano de Lucentum (Benalúa-Alicante): las cerámicas finas. Catálogo de fondos del Museo Arqueológico II. Alicante.

RigOIR, J., 1960: "La céramique paléochrétienne grise. Provence Historique, X. Marsella, pp. 1-93.

$\therefore$ - 1968: "Les sigillées paléochrétiennes grises et orangées". Gallia, XXVI (1). París, pp. 177-244.

RigOIR, J., e Y., 1971: "Les dérivées des sigillées paléochrétiennes en Espagne". RSL,37. Bordighera, pp.33-68.

- 1981: “Chrismes et croix sur les dérivées de sigillées paléochrétiennes". RSL, 47 (1-4). Bordighera, pp.162-188.

- 1987: "Les dérivées des sigillées paléochrétiennes". Céramiques hellénistiques et romaines II. Centre de Recherches d'histoire ancienne, vol. 70. París, pp. 329-338.

RigoIR, J.; RigOIR, Y., y MefFre, J. F., 1973: "Les dérivées des sigillées paléochrétiennes du groupe atlantique. Gallia, XXXI. París, pp.207-263.

RigoIR, Y.; RIGOIR, J., y RIVET, L., 1985: “Les dérivées des sigillées paléochrétiennes. Exportations et influences entre le grupe provençal et le groupe languedocien". Documents d'Archéologie Meridionale, 8. Lambesc, pp.87-99.

ROMERO CARNiCero, M. A., 1974: "Aportaciones al estudio de la distribución en la Península Ibérica de la cerámica romano-visigoda con decoración estampadan. III CNA (Oporto 1974). Zaragoza.

UsCatescu, A.; Fernández OchoA, C., y García, P., 1993: “Las imitaciones locales o regionales de sigillatas grises gálicas tardías halladas en las Termas romanas de Gijón (Asturias)". Trabalhos de Antropologia e Etnologia, 33 (1-2). Oporto, pp.381-396.

Utrilla, P., 1982: -El yacimiento de la cueva de Abauntz (Arrainz, Navarra). Trabajos de Arqueología Navarra, 3. Pamplona, pp.203-345.

VV.AA., 1981: Atlante delle forme ceramiche I. Ceramica fine romana nel bacino mediterraneo (medio e tardo impero). Enciclopedia dell'Arte Antica Classica e Orientale. Roma.

- 1986: Arkeoikuska 85. Investigación Arqueológica. Gobierno vasco. Vitoria.

- 1989: Iruña. Aproximación a la arqueología, 3. Museo de Arqueología de Alava. Vitoria.

ZEISS, H., 1933: :Spätrömische stempelverzierte keramik aus Portugal und Spanien. Revista de Guimaraes. Homenagem a Martíns Sarmento. Guimaraes, pp.467-472. 